\title{
Transient depletion of xDnmt1 leads to premature gene activation in Xenopus embryos
}

\author{
Irina Stancheva and Richard R. Meehan ${ }^{1}$ \\ Genes and Development Group, Department of Biomedical Sciences, University of Edinburgh, Edinburgh EH8 9XD \\ Scotland, UK
}

\begin{abstract}
In Xenopus laevis zygotic transcription begins at the midblastula transition (MBT). Pr to this $t$ genome is organized into chromatin that facilitates rapid cycles of DNA replication but not $t$ hscr, ion. $H$ e we demonstrate that DNA methylation contributes to the overall transcriptional si acing befo o T. Transient depletion of the maternal DNA methyltransferase $(x D n m t 1)$ by anti sense RN furiy, cleavage stages is associated with a decrease in the genomic 5-methyl-cytosine content and 1 ds th acti ction of zygotic transcription approximately two cell cycles earlier than normal. Hypom ylation on the early expression of mesodermal marker genes such as Xbra, Cerberus, and Otx2, whic are bsequenuy down-regulated during gastrulation of the $x D n m t 1-d e p l e t e d$ embryos. The temporal anitch in ne expression may account for the appearance of body plan defects that we observe. Loss of $x D_{1}$ at1 can be rescied by the coinjection of mouse or human Dnmt1 protein. These results demonstrate th: DNA m hylation has a role in the regulation of immediately early genes in Xenopus at MBT.

[Key Words: 5-methylcytosine; Xenopus; DNA methyltr Received August 25, 1999; revised version accepted December 8,

The idea of a heritable, but alterable, swite on D. has an obvious appeal as it could allow for regulatio of a repertoire of genes during embryo uevelo, nent. One candidate for this role as a global odifier of $g$ activity in vertebrates is DNA metatios, the partern of which can be inherited in a re ive stable form in somatic cells (Colot and Ro-iono 999). NA methylation near promoters on cha cer en leads to the stable inactivation of ae ass cinted gene in vitro and in vivo (Bird 1992; Kass o 1997a,b). Methylated CpG pairs act as specific ligand 'or transcriptional repressors (MeCP1 and MeCP2) leading o stable gene inactivation (Jones et al. 1998; Nan et al. 1998). Methyl groups are introduced onto cytosine by enzymes known as DNA methyltransferases (Dnmt), which have been cloned and characterized in many species (Colot and Rossignol 1999). At least three paralogs of this family exist in mouse (Okano et al. 1998) and the most abundant and metabolically active protein, Dnmtlp, was originally characterized as a maintenance methyltransferase (Bestor and Ingram 1983). Hemimethylated DNA is the favored substrate for Dnmt1p, but it also has significant de novo methyltransferase activity in vitro (Pradhan et al. 1997).

DNA methylation is necessary for normal mouse de-

${ }^{1}$ Corresponding author.

E-MAIL Richard.Meehan@ed.ac.uk; FAX 441316503714.

velopment as embryos homozygous for a loss-of-function mutation $\left(D n m t 1^{n / n}\right)$ in the DNA methyltransferase gene die in midgestation (Li et al. 1992), showing evidence of developmental delay and aberrant expression of imprinted genes (Li et al. 1992, 1993). Complex changes in DNA methylation patterns occur during mouse development and cell differentiation that involve a genome-wide demethylation during cleavage followed by a wave of de novo methylation in the growing embryo (Monk et al. 1987; Razin and Kafri 1994). These changes have often been correlated with hypomethylation at tissue-specific loci in the different somatic lineages. However, this view has been challenged by a recent study that showed that many tissue-specific gene promoters are not methylated or expressed in early embryos (Walsh and Bestor 1999). In the case of mammals, it is argued that DNA methylation only has a role in specialized processes such as the maintenance of X-inactivation or imprinting in somatic cells. An examination of $D n m t 1^{n / n}$ mouse embryos has not clarified this point because the observed phenotypes are complex (Li et al. 1992; Lei et al. 1996; Trasler et al. 1996).

Xenopus laevis has a CpG methylation system similar to that of mammals, but relatively little is known about the dynamics of DNA methylation during development. There is no evidence for a global demethylation, imprinting, or inactivation of sex-specific chromosomes in Xenopus (Thiebaud et al. 1984; Tymowska 1991; Ya-
\end{abstract}


mada et al. 1999). The low efficiency of nuclear transplantation experiments (Gurdon et al. 1975), very similar to that in mammals, suggests that epigenetic mechanisms may have a role in determining nuclear competence during Xenopus development.

A period of global transcriptional silence is observed between formation of the activated egg and the midblastula in Xenopus. There are probably several separable events that regulate this developmental switch (known as the midblastula transition or MBT) when there is as much as a 50 -fold increase in the transcription of some genes after the 12th cleavage division (Newport and Kirschner 1982a,b). Experimental evidence suggests that initially chromatin assembly, facilitated by the large pool of maternal histones, is dominant over the construction of the basal transcription complex (Prioleau et al. 1994; Almouzni and Wolffe 1995) and prevents gene activation. Approaching MBT, the competition at promoters can be reversed in favor of the transcription complex when the maternal histone store is lowered and the replication of DNA becomes coupled with histone synthesis. We are interested in whether DNA methylation can contribute to gene silencing before the MBT in Xenopus embryos. An X. laevis oocyte form of DNA methyltransferase $(x D n m t 1)$ has been cloned and the identified protein is highly homologous to Dnmtl proteins from other vertebrates (Kimura et al. 1996). However, the expression pattern of the $x D n m t 1$ gene and its requirement during embryogenesis have not been established. We cloned a partial cDNA $(1.4 \mathrm{~kb})$ corresponding to th served methyltransferase catalytic domain and sed it a probe to follow the expression of $x D n m t 1$ t ugb development. Double-stranded RNA hybr is (cau d by antisense RNA injection) in Xenopus er yos are è ninated by endogenous nuclease activityneadin to the loss of the endogenous mRNA and associat protein (Lombardo and Slack 1997; Stei seissenet al. 19y5). Our results show that antisense $\mathrm{R}$ do setes the maternal $x D n m t 1$ but not the zygotion the en me, leads to hypomethylation of the seno e dur he first embryonic cleavages, allow he in manriate activation of developmentally decisivo nes, and affects the early events of cell differentiatio at the onset of gastrulation.

\section{Results}

\section{Expression of xDnmt1 during Xenopus development}

We isolated a 1.4-kb somatic $x D n m t 1$ clone, $x D n m t 1 p 9 /$ 19 , by screening a stage 20-22 cDNA library (Fig. 1A). The clone had an open reading frame of 373 amino acids and showed $98 \%$ identity with the carboxy-terminal catalytic domain of the full-length (1490 amino acids) oocyte form of $x$ Dnmt1 (Kimura et al. 1996). The protein motifs VIII, IX, and X that are essential for enzyme activity are identical between the somatic and oocyte forms of $x$ Dnmt1 (data not shown).

Northern blot analysis with a $x D n m t 1 p 9 / 19$ probe shows that $x D n m t 1$ or related transcripts are present throughout development (Fig. 1B, top). An mRNA of $5 \mathrm{~kb}$ is observed as an abundant maternal transcript in the mature oocyte and egg. After midblastula (stage 8.5) and during gastrulation (stage 12) the maternal xDnmt1 mRNA is replaced by a somatic form that is present at low levels between stages 16 and 23 and increases at stage 36 (late tadpole). The relative changes in $x D n m t 1$ mRNA levels during development are compared with that of ubiquitously expressed ornithine decarboxylase gene $(O D C)$ in Figure 1B.

For a more detailed analysis of $x D n m t 1$ expression patterns, whole-mount in situ hybridization was performed on eggs and embryos from various stages. The majority of the maternal $x D n m t 1$ transcript localizes to the animal pole in the egg and early hlastula but is hardly detectable in the vegetal pole Ig. E). To test whether the differential localizat of $x D$ r t 1 transcripts in cleavage stage embry is $t$ an in itu hybridization artifact and reflects distrib ion methyltransferase protein in the ear emb $0, x D$ r. 11 p was immunoprecipitated from ext deriy from dissected animal and vegetal alves o the 04 -cell blastulae. Western analysis th monoclo al anti-Dnmtlp antibody (see Materials and $M$ hods for details) of the immunoprecipi atea material veals that $\mathrm{xDnmtlp}$ is very abunda $t$ in the etract of animal hemisphere cells and virtua ly undete table in the vegetal counterpart (Fig. 1K, top). In co trast proliferating cell nuclear antigen CNA is present in equal amounts in both the animal a d vegetal cell extracts (Fig. 1K, bottom). The zygotic form of the $x D n m t 1$ transcript in stage 12.5 gastruae can be observed in the deep cells of the dorsal and entral mesoderm (Fig. 1F) and in the presumptive neural ectoderm during neurulation (Fig. 1G). Generally, a similar pattern of expression is maintained during the tailbud and tadpole stages (Fig. 1H-J). Comparable whole-mount in situ studies in mouse and zebrafish have shown a very similar localization of Dnmt1 and persistently high levels of methyltransferase in neural lineage cells (Goto et al. 1994; Martin et al. 1999). It is conceivable that $x D n m t 1$ is actually expressed in all cells at varying levels, but this will require a more detailed analysis of individual tissues.

\section{Depletion of maternally expressed $\mathrm{xDnmt} 1$}

To determine whether the maternal methyltransferase is essential for early development, animal or vegetal regions of the early embryo were injected with sense or antisense RNA derived from the pxDnmt1-9/19 cDNA clone. Control and injected embryos were cultured until the equivalent of the tadpole stage 35 and monitored during this time for their phenotypic appearance. Alternatively, they were collected at early to midblastula and gastrula stages and analysed for the presence of $x D n m t 1$ RNA and protein.

Figure 2A summarizes the results of the microinjection experiments. Animal blastomeres were targeted first as this is where we observed the highest levels of $x D n m t 1$ mRNA. The injection of $520 \mathrm{pg}$ per cell of sense RNA into the animal pole of two- and four-cell blastulae 
A
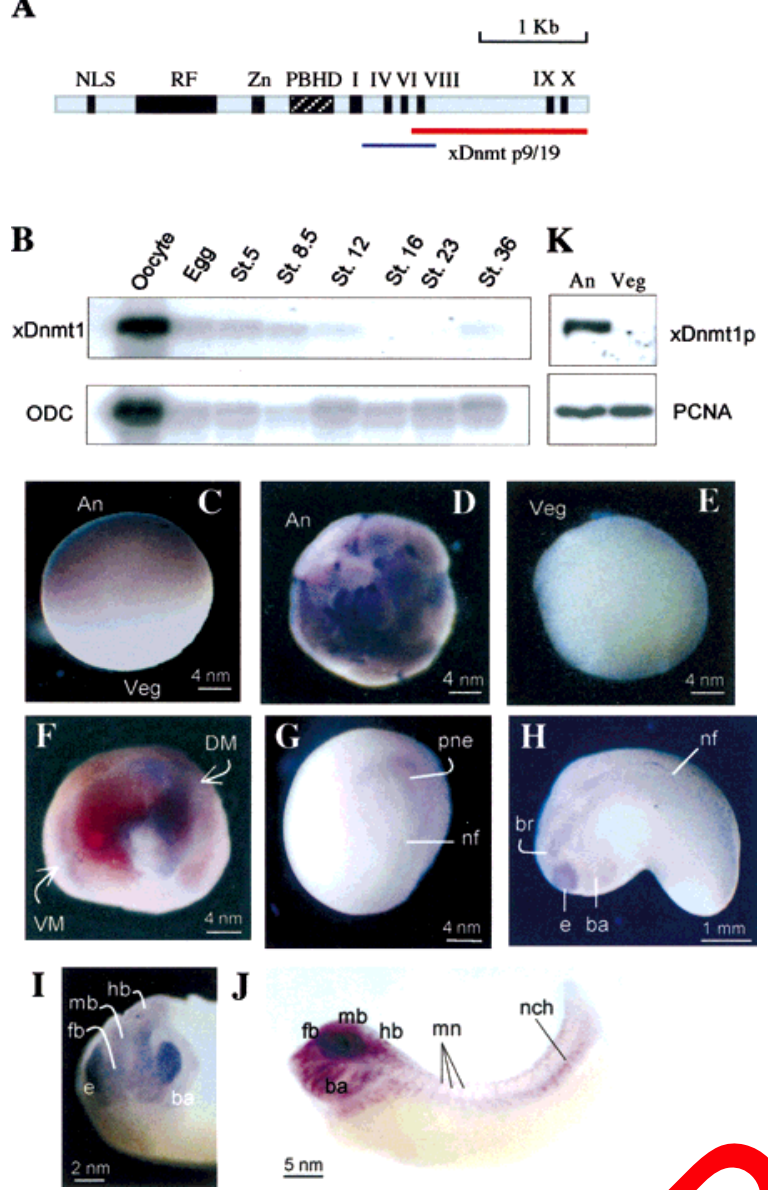

Figure 1. Expression of $x D n m t 1$ during Xenopus do lopm (A) The functional domains of the $\mathrm{xDnmtl}$ prote are $\mathrm{n}$ as shaded and solid boxes. (NLS) Nuclear locali ion signa $(R F$ region involved in targeting of the enzym to lication $\mathrm{i}$; (Zn) cystine-rich Zn/DNA-binding mot $\%$ (PBHD) yybromo-1 protein homologous domain; I-X are conserved mo fs of the methyltransferase catalytic domai the $1 \mathrm{~kb}$ partial somatic $x$ Dnmt1 cDNA (st. 20-22) is $98 \%$ on logous to the oocyte $x D n m t 1$ catalytic domain (re product used to detect y $n$ mt I deplea nigure 3A. (B) Northern blot analysis $x$ Dnp 1 transcipts during embryo development. Ornithine woxylas (ODC) is an ubiquitously expressed gene. Stag of development are indicated above the $x D n m t 1$ blot. $(C, D)$ yole-mount in situ hybridization localizes $x D n m t 1$ transcripts (pink) to the animal pole of albino Xenopus egg $(C)$ and animal pole blastomeres of 64-cell blastula $(D)$. (An) Animal pole; (Veg) vegetal pole. (E) xDnmt1 is not detected in the vegetal hemisphere of 64-cell blastula. $(F)$ After MBT the somatic form of $x D n m t 1$ appears in the deep cells of the dorsal (DM) and ventral (VM) mesoderm of stage 11 gastrula (sagittal section). (G) During neurulation at stage 15 the staining for $x D n m t 1$ transcripts is localized in the eye (e) and brain regions (br) of the prospective head neuroectoderm (pne) and along the edges of the open neural fold (nf). $(H, I)$ A similar pattern is maintained during tailbud stages $20(F)$ and $23(G)$. (fb) Forebrain; (mb) midbrain; (hb) hindbrain. (J) At stage 35 (tadpole) the methyltransferase probe stains eyes, brain regions, branchial arches (ba), posterior notochord (nch), and the motor neurons $(\mathrm{mn}) .(K) \mathrm{xDnmt1}$ protein $(\mathrm{xDnmt} 1 \mathrm{p})$ was immunoprecipitated from extracts derived from animal or vegetal halves of 64-cell blastulae and detected by Western blot analysis. Both extracts contain equal amounts of PCNA (bottom). had no noticeable effect on embryo survival or appearance when compared with noninjected controls (Fig. $2 \mathrm{D}, \mathrm{E})$. In contrast significant developmental abnormalities appear when antisense $x D n m t 1$ RNA is injected into two- and four-cell embryos at a dose of $>120$ pg per cell. Embryos injected with 520 pg of antisense exhibit considerable delay in closing the blastopore in comparison with control embryos of the same stage (Fig. 2B,C). When they were allowed to develop further, doses of 400 and $520 \mathrm{pg}$ of antisense led to the appearance of a microcephalic phenotype (Fig. 2F) in some cases accompanied by axis truncation (Fig. 3F). A considerable number of the antisense-injected embryos die during gastrulation and neurulation (Fig. 2A). An even more severe effect was caused by injection of 400 p of ans ense RNA into each of the animal blastomere of 8 - and 5 -cell stage where $90 \%$ of the embryos sto 35 eit er exhibit severe developmental defe sor arres at strulation and neurula stages. To th whe er the affect of the antisense was specific to nin slastores, $520 \mathrm{pg}$ of this RNA was injecter nto the a s getal cell of four- and eightcell blast ae. The vast hadority of these developed normally.

$\mathrm{T}$ test whether he injection of $\mathrm{xDnmt1}$ antisense RI A leads te loss of the endogenous maternal transcript we erformed quantitative RT-PCR reactions with a pair of p ners erlapping the junction of sense and antinse RIvA (see Fig. 1A). Fig. 3A shows that 600 pg of and per cell injected into each animal pole blastomere of 2- and 4-cell embryos is sufficient to decrease the level of the maternal $x D n m t 1$ transcript to $<5 \%$ of that detected in the normal 64-cell blastula. $x D n m t 1$ protein is also barely detectable in the depleted blastula stage embryos (Fig. 3B). At gastrula, to our surprise, both $x D n m t 1 \mathrm{mRNA}$ and protein are upregulated in the antisense injected embryos (Fig. 3A,B). These results were also confirmed by in situ hybridization with a 5' xDnmt1 probe (Fig. 3C,D). The unstable antisense RNA does not appear to interfere with the zygotically expressed form of $x D n m t 1$, as the $x D n m t 1$ transcript and protein appear at much higher levels in the antisense injected gastrulae (see Fig. 3A,B) compared with the normal embryos. It is clear that a transient depletion of $x$ Dnmt1 during blastula stages causes developmental abnormalities and sets in motion a series of events that results in subsequent changes in the pattern of expression of the zygotic form of $x D n m t 1$.

\section{Rescue of the antisense xDnmt1 RNA phenotype}

To ascertain whether the phenotype of $x D n m t 1$ depleted embryos is due to the loss of methyltransferase activity we attempted to rescue the antisense embryos by coinjection of antisense $x$ Dnmt1 RNA with either human or mouse Dnmt1 proteins (Pradhan et al. 1997) into the animal hemisphere of two- and four-cell blastulae. Coinjection with hDnmtlp or mDnmtlp reverses the antisense RNA effect in a dose-dependant manner (Fig. 4A). hDnmtlp (4 pg) cannot change the mutant phenotype of the antisense injected embryos (Fig. 4B), whereas $12 \mathrm{pg}$ of 
$\mathbf{A}$

\begin{tabular}{|c|c|c|c|c|c|c|}
\hline $\begin{array}{l}\text { xDnmt 9/19 RNA } \\
\text { microinjected }\end{array}$ & $\begin{array}{c}\text { Total } \\
\mathrm{n}\end{array}$ & $\begin{array}{l}\text { Normal } \\
\mathrm{n}(\text { () })\end{array}$ & $\begin{array}{l}\text { Microcephaly } \\
\mathrm{n}\left(\Phi^{\circ}\right)\end{array}$ & $\begin{array}{c}\text { Microcephaly, } \\
\text { truncared axis } \\
\mathrm{n}\left(\mathscr{S}_{0}\right)\end{array}$ & $\begin{array}{l}\text { Die at gastrula } \\
\mathrm{n}(\mathscr{F})\end{array}$ & $\begin{array}{l}\text { Die during } \\
\text { neurulation } \\
\mathrm{n}(\%)\end{array}$ \\
\hline - & 60 & $56(93.3)$ & $1(1.6)$ & 0 & $3(5)$ & 0 \\
\hline $\begin{array}{l}2 \text { and } 4 \text { cell } \\
520 \text { pg sense }\end{array}$ & 60 & $54(90)$ & 3 (5) & 0 & $3(5)$ & 0 \\
\hline $\begin{array}{l}2 \text { and } 4 \text { cell An. } \\
120 \mathrm{pg} \text { antisense }\end{array}$ & 79 & $63(79.7)$ & 7 (8.8) & 0 & $5(6.5)$ & $4(5.2)$ \\
\hline $\begin{array}{l}2 \text { and } 4 \text { cell An. } \\
400 \text { pg antisense }\end{array}$ & 39 & $18(46.2)$ & $5(12.5)$ & $6(15.4)$ & $10(25.6)$ & $6(15.3)$ \\
\hline $\begin{array}{l}8 \text { and } 16 \text { cell An. } \\
400 \mathrm{pg} \text { antisense }\end{array}$ & 42 & $4(9.5)$ & $10(23.8)$ & $13(30.9)$ & $7(16.6)$ & $8(19)$ \\
\hline $\begin{array}{l}2 \text { and } 4 \text { cell An. } \\
520 \text { pg antisense }\end{array}$ & 82 & $27(32)$ & $14(7.7)$ & $26(29.2)$ & $11(13.4)$ & $6(7.3)$ \\
\hline $\begin{array}{l}4 \text { and } 8 \text { cell Veg. } \\
400 \mathrm{pg} \text { antisense }\end{array}$ & 56 & $46(885)$ & $2(3.8)$ & 0 & $2(3.8)$ & $2(3.8)$ \\
\hline
\end{tabular}
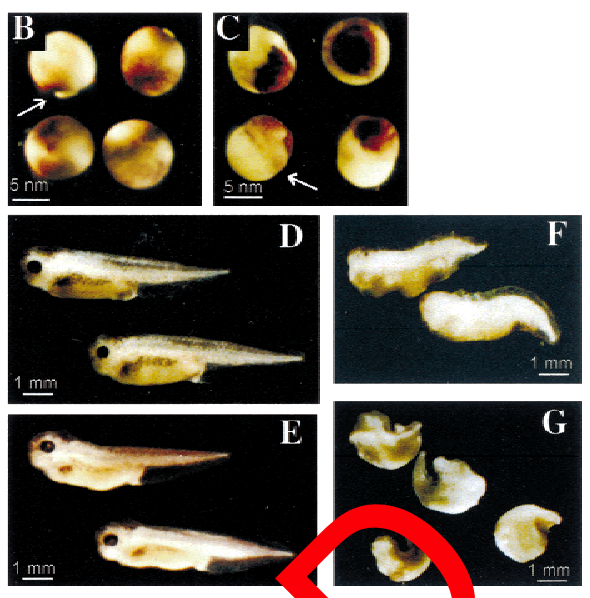

Figure 2. Phenotypes of sense and antisense $x D n m t 1$ RNA-injected embryos. (A) Table show so the pnotyp of stage 35 embryos after injection of synthetic xDnmt1 RNA. (B) Four control embryos (stage 12.5-13) undergoi ormal gas y on and almost closing the blastopore (indicated by arrow). (C) The injection of $520 \mathrm{pg}$ of antisense $x$ Dnmt1 RNA to thimal pue at two-cell stage slows gastrulation and disturbs the convergent extension movements of ectomesoderm. four resentative gastrulae at the equivalent of stage 12.5-13. Note the extended appearance of the embryos and the lo blastop (in cated by arrow). (D) Uninjected control embryos at stage 35. (E) Injection of $520 \mathrm{pg}$ of sense xDnmt1 RNA into tw an four-cell $\mathbf{s}$ sulae or $400 \mathrm{pg}$ of antisense RNA into the vegetal pole does not lead to any visible developmental abnormalities. ( $F$ ) The in ction of a low dose antisense RNA (400 pg) into the animal pole of two- and four- cell blastulae causes the embryos to on microcally as shown at the equivalent of stage 35. $(G)$ The injection of a high concentration $(520-600 \mathrm{pg})$ of the antisens RNA leads to considerable shortening of the dorsal axis in addition to microcephally.

hDnmt 1 or mDnmtl can restore their appearance in $85-$ $90 \%$ of the cases (Fig. 4C). In the remaining cac $10 \%$ ) the rescue is only partial where the embr os ha normal heads but still exhibit axis defects (Fig. D). T suggests that either cross-species methylt isfer protein cannot completely substitute for functio of $x D n m t$ or, alternatively, that the endogenow concentration and distribution of xDnmt 1 cannot bo vroperly mimicked by microinjection reconbinant proteins. Higher amounts of hDnmt 140 of cotein per embryo) coinjected with the antisone $\mathrm{x}$. $m t 1 \mathrm{P} A$ result in embryos that develop $y$ ster $r$ den very similar to these caused by an in ction $12 \mathrm{gg}$ or $\mathrm{hDnmtl}$ protein alone into the cells of egetannemisphere (Fig. 4F). When injected into anima vole cells, $12 \mathrm{pg}$ of hDnmt 1 protein causes a "no-axis" p. notype (Fig. 4E) and there is a failure to develop past gastrulation. The injection of a comparable amount of BSA had no effect on development in normal or mutant embryos. These experiments imply that, to a large extent, xDnmtlp function can be substituted by cross-species DNA methyltransferases during Xenopus embryo development. In addition higher than normal levels of Dnmt1 proteins cannot be tolerated either by the animal or vegetal cells of the embryo.

\section{DNA methylation levels in normal and antisense $\mathrm{xDnmt1-injected} \mathrm{embryos}$}

We wished to know whether loss of the $x D n m t 1$ transcripts leads to changes in DNA methylation levels during the cleavages of the antisense injected depleted embryos. A 5-methyl-cytosine $\left(\mathrm{m}^{5} \mathrm{C}\right)$ monoclonal antibody

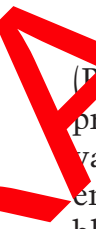

(P cy d et al. 1992; Tweedie et al. 1997) was used as a probe for the methylation content in DNA isolated from various stages of normal and antisense RNA-injected embryos along with control DNA samples from Xenopus blood, sperm, and the yeast, Saccaromyces cerevisiae. As expected, the antibody detects Xenopus blood and sperm DNA samples from the normal embryos but the signals progressively decreases towards gastrulation (64 cell and stage 7) and is restored to the initial levels at late neurala stages. We did not observe any global demethylation and remethylation of DNA during these particular stages (Fig. 5A, C, WT), if such an event takes place then it may occur prior to the 64 to cell stage or alternatively in a specific subset of cells in the developing embryo. The latter possibility is supported by our observation that DNA derived from the animal pole cells is up to three times more methylated than the equivalent sample of vegetal pole from 64- to 128 -cell blastulae (Fig. 5A,C), which correlates with the polarized localization of $x D n m t 1$ transcripts and protein in the cleavage stage embryos (see Fig. 1D,K). More detailed analysis will be required to clarify the significance of these differences in methylation levels between distinct subsets of cells in the pre-MBT Xenopus embryo. In contrast to the controls, the antibody was almost unable to detect the sample from stage 7 antisense injected embryos DNA although it could detect the 64-cell stage and stage 12 samples (Fig. 5A,C, AS). Later stages (19-35) gave a signal that was comparable to and even slightly higher than that of the control embryo samples. The blot was stripped and reprobed with a mixture of total Xenopus and yeast DNA to illustrate the equal loading of DNA on 

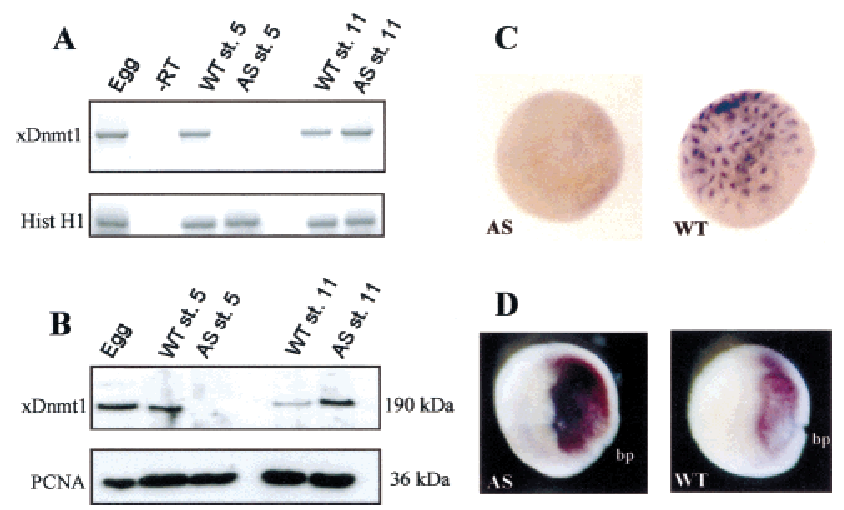

Figure 3. Microinjection of antisense $x D n m t 1$ RNA transiently depletes the maternal $x D n m t 1$ transcripts and protein during cleavage stages. (A) RT-PCR analysis of $x D n m t 1$ in RNA samples from wild-type blastulae (WT st.5) and antisense RNAinjected blastulae (AS st.5), wild-type (WT st.11) gastrulae, and antisense-injected (AS st. 11) gastrulae. The location of RT-PCR product with respect to $x D n m t 1$ sequences and the antisense RNA is shown in Fig. 1A. Histone H1 (Hist H1) transcripts are present in equal amount in all RNA samples. $(B)$ Protein extracts derived from wild-type (WT) and antisense RNA-injected (AS) embryos as in $A$ were analyzed for the presense of $x D n m t 1$ by a carboxy-terminal polyclonal antibody. PCNA immunodetection is a loading control. $(C)$ In situ hybridization with a $5^{\prime}$ $x D n m t 1$ probe confirms that the $x D n m t 1$ transcripts (purple) are missing from the antisense-injected stage 6 blastula (AS) in comparison to a control embryo (WT) at the equivalent stage (viewed from the animal pole). (D) Sagittal section after in situ staining (magenta) with $5^{\prime} \mathrm{xDnmt1}$ probe of stage 10 shows that the zygotic $x D n m t 1$ transcript is overpro ing gastrulation in the maternal $x D n m t 1$-depleted in the same region as in the control gastrula ( the right; (bp) blastopores.

the filter (Fig. 5B). We obtaine similar resur using methylation-sensitive restric on e cymes (data not shown). The observed changes in con appear to reflect changes in $x D n n-\mathrm{m}$. $\mathrm{NA}$ otein levels in both normal and $x D p$ st 1 -de leted en oryos.

\section{Depletion of xDnmt1 leads premature activation of transcription at $M B T$}

Because DNA methylation is known to repress transcription via the binding of transcriptional repressors, we asked whether the abnormalities in development that we see might be due to the premature gene activation through a global hypomethylation. Zygotic transcription usually initiates at stage 8.5 (also known as MBT) of development. As a test of transcriptional activation, we measured the incorporation of $\alpha{ }^{35}$ S-labeled UTP in control, sense, and antisense $x D n m t 1$ RNA-injected blastulae and gastrulae (Fig. 6A,B). In each case RNA was prepared from three sets of staged embryos (15 embryos per time point) that had been microinjected with $\alpha-{ }^{35} \mathrm{~S}$-labeled UTP. The control and sense-injected embryos did not incorporate label above background levels until stage 9 of development (Fig. 6A). In contrast we detected up to a fourfold increase in incorporation of $\left[\alpha^{-35}\right.$ S UTP much earlier in the $x$ Dnmt1-depleted embryos at stage 7 , but the level of activation is $<50 \%$ of that seen at stage 9 for control, sense-, and antisense-injected embryos (Fig. 6, cf. A and B). This experiment led us to conclude that $x D n m t 1$-depleted embryos initiate zygotic transcription approximately two cell cycles before MBT. To determine which type of genes, either transcribed by RNA polymerase I, II, or III, contribute to the increased incorporation of $\left[\alpha-{ }^{35}\right.$ S $]$ UTP in antisense-injected blastulae we made use of the differential sensitivity of RNA polymerases to the inhibitor, $\alpha$-amanatin. Low concentrations of $\alpha$-amanatin $(0.2 \mu \mathrm{g} / \mathrm{ml})$ inhibit RNA polymerase II transcription only, and this led to $50-60 \%$ decrease in

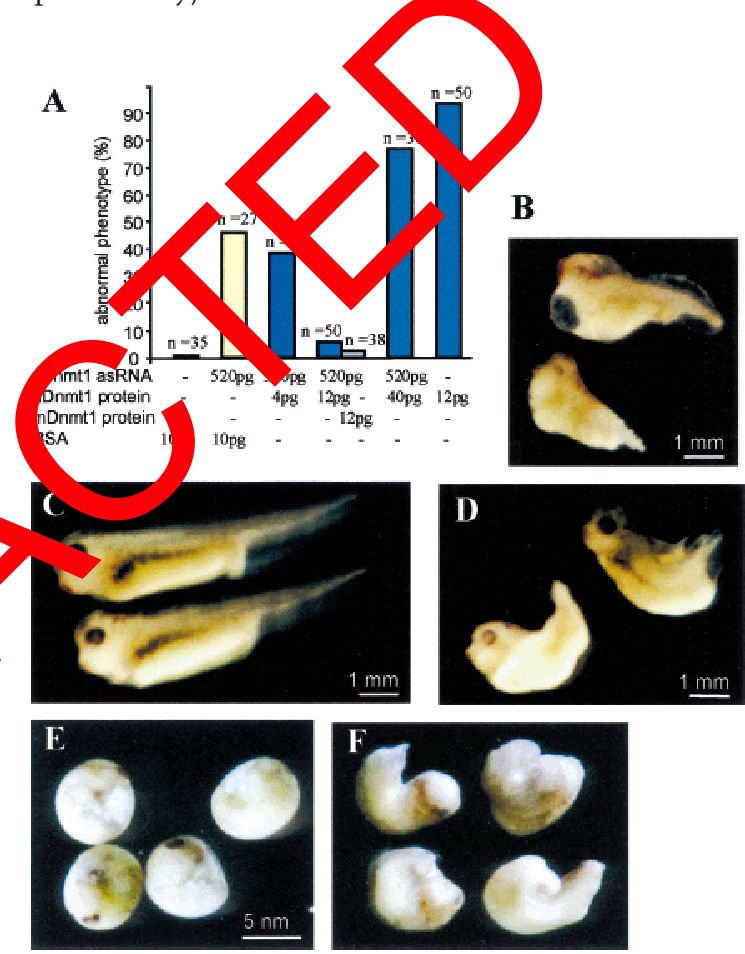

Figure 4. Cross-species Dnmt1 proteins can substitute for the function of maternal $x D n m t 1$ depleted by antisense RNA injection. (A) Microcephalic and axis-truncated phenotype of $x$ Dnmt1-depleted embryos can be rescued in a dose-dependent manner by coinjection of recombinant human (hDnmt1) or mouse (mDnmtl) Dnmtl proteins with 520 pg of antisense $x$ Dnmt1 RNA. The percentage of resulting abnormal embryos scored at stage 35 was plotted for the experiments indicated underneath the bars. (n) Number of injected two-cell blastulae. Yellow indicates injection of antisense only; blue indicates injection of antisense plus recombinant hDnmtlp protein; light blue indicates injection of antisense plus recombinant mDnmtlp protein. $(B)$ Both proteins $(4 \mathrm{pg})$ cannot rescue the microcephalic phenotype. (C) Coinjection with $12 \mathrm{pg}$ of human or mouse Dnmt1 protein in the majority of cases can restore the normal appearance. $(D)$ The rest of the embryos have normal or even enlarged heads, but still a very short axis. $(E)$ hDnmtl protein $(40 \mathrm{pg})$ coinjected with the antisense RNA results in no-axis phenotype similar to that caused by injection of $12 \mathrm{pg}$ of hDnmtl protein alone into the animal pole at two-cell stage. $(F)$ Vegetal pole cells are sensitive to the same amount (12 pg) of hDnmtl protein injected alone. Vegetal injection into two-cell blastulae leads to multiple defects as shown at stage 35 . 
$\mathbf{A}$
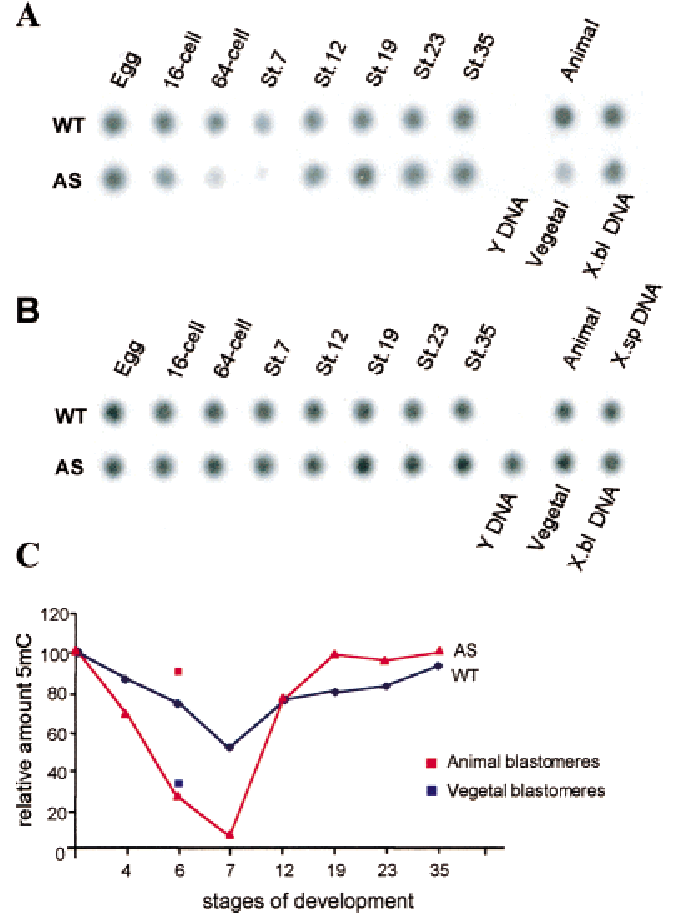

Figure 5. Changes in the levels of 5-methylcytosine $\left(\mathrm{m}^{5} \mathrm{C}\right)$ during development of wild-type and $x$ Dnmt1-depleted embryos. (A) $\mathrm{m}^{5} \mathrm{C}$ was detected in the DNA of wild-type (WT) and $x$ Dnmt1-depleted (AS) embryos at the indicated stages (from egg to stage 35 tadpole). The antibody does not recognize the nonmethylated $S$. cerevisae DNA (Y DNA). Note that higher levels (approximately three fold) of $\mathrm{m}^{5} \mathrm{C}$ in the derives from the animal pole blastomeres (An) than from the vegetal cells (Veg). (X.bl) Xenopus b od an (. sp Xenopus sperm DNA samples. (B) The blo own in as stripped from the antibody and rehybridiza wit mixturen of Xenopus and $S$. cerevisae DNA to ill strate the yal DNA loading. $(C)$ The relative amount $a^{5} \mathrm{C}$ in DNA 0 normal (WT) and $x D n m t 1$-depleted (AS) s ed Xe pus embryos as detected by the antibody in $A$ in app ate ur value. The wild-type oocyte DNA samr tak as andard (100\%).

$\alpha-{ }^{35}$ S]UTP incorporation both normal and antisenseinjected embryos (Fig. 6A, A higher dose of $\alpha$-amanatin $(20 \mu \mathrm{g} / \mathrm{ml})$, which inhibi the transcription of RNA polymerase II and polymerase III, decreased $\left[\alpha-{ }^{35}\right.$ S ]UTP incorporation to about $15-20 \%$ of that seen in the absence of the drug in both types of embryos, the remaining incorporation probably corresponds to RNA polymerase I transcription. The changes of $\left[\alpha-{ }^{35}\right.$ S UTP incorporation that we observe suggests that all three types of RNA polymerases (and their associated genes) are activated in the $x D n m t 1$-depleted embryos, which implies that there might be a general relaxation in chromatin structure that allows transcription to occur. In normal blastulae it is known that embryogensis is dependent on specific transcriptional cascades that are set in motion after MBT by maternally stored factors (Harland and Gerhart 1997), it is possible that this process has been disrupted by loss of DNA methylation. The net result of hypomethylation of DNA is that many genes, at least half of which are RNA polymerase- II-regulated, are not activated in their proper developmental context.

Analysis of gene expression in methylation-depleted embryos

We attempted to identify some of the transcripts that appear prematurely in the $x D n m t 1$-depleted embryos by focusing on the expression level of mesoderm-specific molecules, ubiquitous and tissue-specific genes. RT-PCR analysis demonstrated that in $x D n m t 1$-depleted embryos the transcripts for the secreted signaling peptide Cerberus (Bouwmeester et al. 1996) and the transcription factor Xbra (Smith et al. 1991. Rouwmeester et al. 1996) are both present at detectab leve at stage 7 (Fig. 6C). The maternally express transcri tion factor Otx2 (Pannese et al. 1995) i also p-regul ed. We could not detect any transcrip that belo to issue-specific genes such as muscle-s, cific ctin on eural $\beta$-tubulin (data not shown), no con we det $t$ any discernible change in the abun nce of the hechromatin proteins (HP1) $\alpha$ and $\gamma$ i the Dnmt1-cpleted embryos (Fig. 6C). The transcrints for her histones $H 1$ and $B 4$ were also presen in equal amounts in both control and antisensein cted emb yos (data not shown). If there is a change in the expressio of ubiquitously expressed genes then it is muc less amatic than that detected for the mesorom-inuucing molecules when compared to the control thopts of $E F 1 \alpha$ and $H 4$.

Whole-mount in situ hybridization on normal and deleted embryos at stage 7-7.5 was used to localize some of the up-regulated transcripts (Fig. 7A-C) in comparison with the nonexpressing control blastulae (Fig. 7D). In the antisense-depleted embryos, Cerberus transcripts are nonuniformly detected in the most anterior region of the animal pole cells (Fig. 7A). Xbra expression does not coincide with that of Cerberus but is present at the lateral dorsal area of the animal hemisphere (Fig. 7B). Neither gene was ectopically expressed in the vegetal cells (Fig. 7C). This localized pattern of both transcripts in the $x$ Dnmt1-depleted embryos resembles their expression during later stages of gastrulation in normal embryos (Bouwmeester et al. 1996), as they appear to be at the right place in the maternal morphogen gradient in a nonoverlapping pattern. In addition, injection of antisense $x$ Dnmt1 RNA into a single dorsal animal cell (D1) of eight-cell blastulae allows ectopic expression of Xbra (Fig. 7F,G) and Cerberus (Fig. 7I,J) in subsets of cells that are depleted of methyltransferase (Fig. 7E- -G,I,J). The activation of Cerberus, Xbra, and Otx2 occurs despite the fact that all of the repressive chromatin components that we analyzed are still present. Overall our analysis suggests that only genes whose promoters normally respond to maternally stored transcription factors are induced by changes in DNA methyltransferase activity.

We also found that the mesodermal markers Cerberus, $X$ bra, and Otx2 are down-regulated at the equivalent of mid-gastrulation (stage 12) in the mutant embryos (Figs. $6 \mathrm{D}$ and $7 \mathrm{~L}, \mathrm{M})$. In normal gastrula embryos there is prominent staining for Xbra around the blastopore, 
A

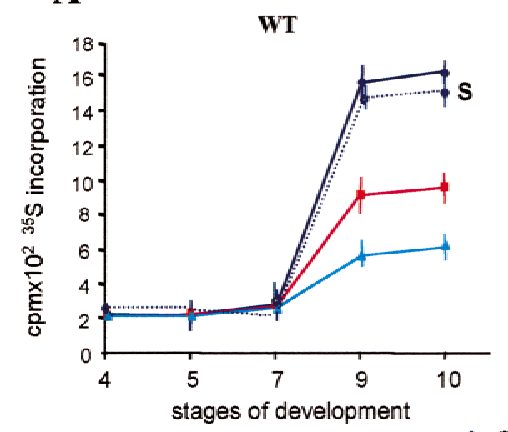

$\neg$ no $\alpha$-amanitin

$\rightarrow 0.2 \mathrm{mg} / \mathrm{ml} \alpha$-amanitin

- $20 \mathrm{mg} / \mathrm{ml} \alpha$-amanitin

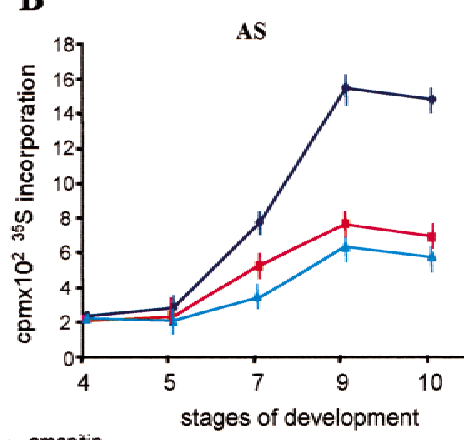

Figure 6. $x D n m t 1$-depleted embryos initiate zygotic transcription before MBT. (A) The incorporation of microinjected (50 nCi) $\left[\alpha-{ }^{35}\right.$ S]UTP was used to detect the activation of gene expression in wild-type (WT) and sense $x D n m t 1$ RNA (S) injected embryos. Wild-type blastulae were grown also in the presense of $\alpha$-amanitin for the indicated amounts. $(B)$ Embryos injected with antisense RNA and $50 \mathrm{nCi}\left[\alpha_{-}{ }^{35}\right.$ S $]$ UTP (AS) at two-cell stage were cultured in parallel to the wild-type siblings and collected at me time points as in $A$ indicated on the grar $(C) \mathrm{R}-1$ derived from wildtype (wt) and antise -injected / / embryos at stage 7 was assayed by $\mathrm{T}$-PC for the anscripts of the mesodermal mar ar genes ( 0 b, Y ra, Otx2), chromatinrelated pro ns $(R P \beta, H P-$ and $\gamma)$ and ubiquitously expresse $E A, V T$ RT-PC analysis of normal (wt) and $x D n y$-deplet (as) g bryos at stage 11.5. Cerberus, $X b \leadsto$ d Otx2 a cown-regulated in the $x D n m t 1$ depleted strulae. RPD3 and $H P 1 \alpha$ are present at gher than ormal levels. (E) RT-PCR analysis of normal (wt) and XDnmt1-depleted (as) embryos for the expressi of the homeobox containing genes HoxB3 and HoxB neural $\beta$-tublin (N $\beta$ tub), muscle-specific actin $(\mathrm{Mar}$, and histone $\mathrm{H} 4$ (Hist H4). (F) Antisense gastrulae rescued with $12 \mathrm{pg}$ of mouse Dnmt1 protein (as $+\mathrm{hDnmt} 1$ ) contains similar to wild-type (wt) levels of Cerberus, Xbra, xDnmt1, RPD3, and histone H4 transcripts. The expression of Otx2 always remained lower in the WT embryos. In $C-E$ and $F,-\mathrm{RT}$ is a control PCR reactions of the antisense embryo RNA sample without reverse transcription. which is considerably reduced in re $x$ Dnmt. tepleted siblings (Fig. 7M, cf. AS and WT. The ame is onserved for Cerberus expression in the embryos (Fig. 7L). The diminished expression of sentiz/mesodermal markers and the appea nce mic shalic and axistruncated phenotypes n the aticense injected embryos suggests that both anten and posterior parts of the mesoderm are affected by the eficiency of $x D n m t 1$ during blastula stages. This by itsed can lead to the decreased expression of the posterior homeobox gene Hox $B 9$ and tissue-specific markers such as neural $\beta$-tubulin in stage 15 neurula (Fig. 6E). At the same time we saw up-regulation at gastrula of the major Xenopus histone deacetylase gene (RPD 3), HP1 $\alpha$, and, as noted earlier, the zygotic form of DNA methyltransferase (Figs 6D and 3A). The fact that most of the transcripts that show higher than normal levels belong to proteins associated with heterochromatin formation suggests that they might be regulated by a common pathway involving prematurely activated genes.

We also tested the expression of mesodermal and tissue-specific markers at mid-gastrula in the antisense-injected embryos that had been rescued by the coinjection of hDnmtlp (Fig. 6F). In all cases the expression of the analyzed genes was restored to wild-type levels with the exception of Otx2, which was always reproducibly higher in the rescued embryos.

\section{The DNA methylation pattern of the Xbra promoter in normal and antisense-depleted embryos}

We decided to test whether the premature activation of Xbra can be correlated with changes in the pattern of methylation of its promoter region (Artinger et al. 1997; Latinkic et al. 1997). Sequence analysis indicates that there is a considerable number of CpGs clustered around either the transcription initiation site (Fig. 8A) or an upstream region that is essential for the dose-dependent response of Xbra to TGF $\beta$-activin (Latinkic et al. 1997). We analyzed the sequence from -267 to +203 using a methylation-dependent PCR assay (Singer-Sam et al. 1990) that has been modified for the use of one forward and two reverse primers (see Fig. 8A). The longer 470-bp PCR product spans three restriction sites for enzymes (1 HpaII and 2 HhaI sites) that are inhibited by CpG methylation. When DNA is digested with HpaII and HhaI and subjected to PCR amplification, the longer PCR product will appear only if the sites are methylated. The shorter PCR product does not traverse the restriction sites but will appear at a higher molar ratio upon digestion be- 
Figure 7. Localization of mesodermal markers in xDnmt1-depleted embryos before and after MBT. (A) Cerberus transcripts were detected by in situ hybridization in $x D n m t 1$-depleted albino blastulae at stage 6.5. The albino embryos were injected symmetrically with $x D n m t 1$ antisense RNA (as shown on the drawing). Cerberus transcripts localize predominantly to the most anterior animal blastomeres (purple staining). Animal view of the embryo. (B) Xbra transcripts (purple) in the antisense blastula of the same stage (6.5) appear around the midline zone (dorsal and ventral) and never overlap with the pattern of Cerberus expression. Animal pole view of the blastula. $(C)$ Neither of the two transcripts are aberrantly expressed in the vegetal pole blastomeres of the antisense injected embryos (hybridization with Xbra is shown). (D) Wild-type blastula at stage 6.5 do not express Cerebrus or Xbra (control hybridization with Cerberus). (E) Ectopic injection of antisense RNA and $\beta$-gal sense RNA into a single dorsal animal blastomere (D1) of eight-cell blastulae (as indicated on the drawing) depletes $x D n m t 1$ transcripts in a portion of animal pole cells. Only the staining for $x D n m t 1$ is shown (red). (F) Few cells of the dorsal midline zone express ectopically high levels of Xbra (purple). $(G)$ The ectopic Xbra expression (dark blue) colocalizes with the staining for $\beta$-gal (blue) on the injected site of a stage 6.5 blastula. Note that Cerberus and Xbra expression localize to different populations of cells. The staining for $x D n m t 1$ is in red. $(H)$ Uninjected embryd stage 6 does not express Xbra or Cerberus. $(I)$ A few of the most anterior animal cells that coincide with the site of $x D+1$ deple blastula. $(J)$ The staining for Cerebrus transcripts colocalizes wit thra the $\beta$-gal tracer. $(K)$ The control embryo at the same stage (6.5) injected with $\beta$-gal RNA only do not show any staining for $O$ be as on bra (control hybridization with Cerebrus probe). (L) In $x$ Dnmt1-depleted embryo (AS) at stage 12 the staining transcripts is reduced compared to a wild-type (WT) gastrula (Cerebrus in dark brown to black). The remaining tra cripts till lo lize to the most anterior regions of dorsal mesoderm. (M) Xbra (dark brown to black staining) is dramatically reduc in $x D$ theted gastrula at stage 12.5 (AS) as compared with the wild-type (WT) embryo.

cause of the unbalanced concent tion of therse PCR primers (see Materials and ethods). The argree of methylation is indicated by ne ro of the 470-bp (methylated) versus 249-bn/non, chylat A PCR products, which can be calcy itea rom to dard curve that
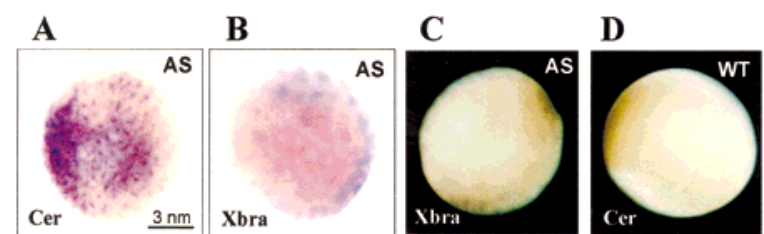

E

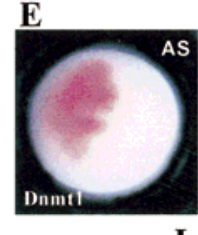

F

G

H

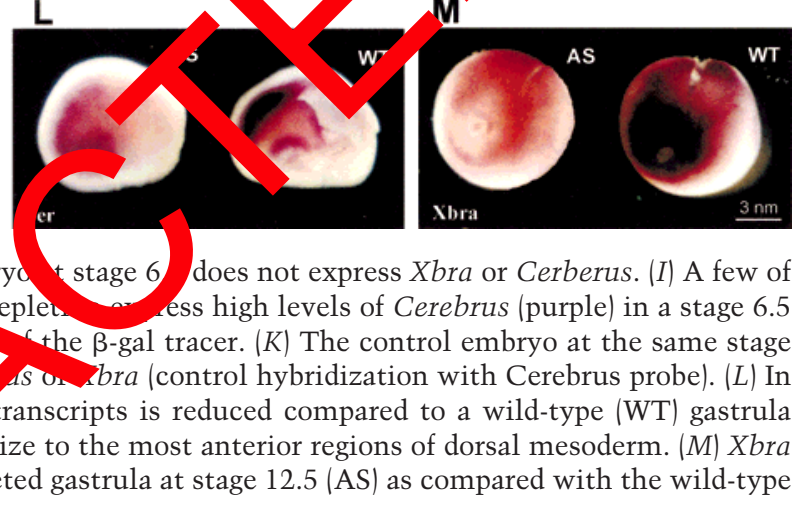

Figure 8. Sequences of Xbra comoter are hypomethylated earlier in $x D n m t 1$-depleted embryos. (A) Schematic presentation of 1.6-kb region that covers the promoten d the first exon of Xbra gene. The CpG pairs in the sequence are shown by vertical lines. Underneath the CpG plot are indicated HpaII and HhaI sites. The position of transcriptional initiation is marked by an arrow. Sequences that were analyzed by methylation-sensitive PCR during development are shown on the expanded region below. A 470-bp PCR product covers the sequences between -267 and +203 where there are two HhaI (Hh) sites and one HpaII (H) site. The 470-bp band is produced only if the methylation-sensitive enzymes HpaII and HhaI do not cleave in these sites. When the restriction sites are cleaved it results in the appearance of 249-bp PCR product and is indicative of hypomethylation (see Materials and Methods). Digestion with MspI (which is not methylation sensitive) gives rise to the shorter product only. $(B)$ To create a quantitative standard curve, a plasmid containing the Xbra promoter and part of the first Xbra exon (Latinkic et al. 1997) was methylated in vitro by SssI methylase and mixed with nonmethylated Xbra plasmid in the combinations shown. The mixtures were digested with HpaII and HhaI and used for PCR amplification resulting in fragments of 470 and 249, respectively. The percentage of methylation is indicated on top of each lane. M is a 100-bp DNA marker. (C) Standard curve generated from plotting the ratio of 470/249 fragments (X axis) against the percentage of DNA methylation (Y axis). (D) Genomic DNA samples from staged embryos indicated by numbers from 4-40 (stage) were digested with HhaI and HpaII and analyzed by methylation-sensitive PCR. (E) Genomic DNA samples of the $x D n m t 1$-depleted embryos at equivalent stages to the wild type in $B$, indicated by numbers from 4 to 35, were digested with HhaI and HpaII, and subjected to PCR analysis as in $B .(F)$ The same of set of DNA samples as in $D$ was digested with MspI and analyzed as above. (G) Graphical plot of methylation changes in Xbra promoter during development of the normal (WT) and $x$ Dnmt1-depleted (AS) embryos. The ratio of 470-bp to 249-bp PCR products for each sample was quantitatively estimated and plotted against a standard curve to give the amount of methylated Xbra promoter as a \% of the total Xbra promoter sequences present in the PCR reaction of genomic DNA at the indicated stages. 
A
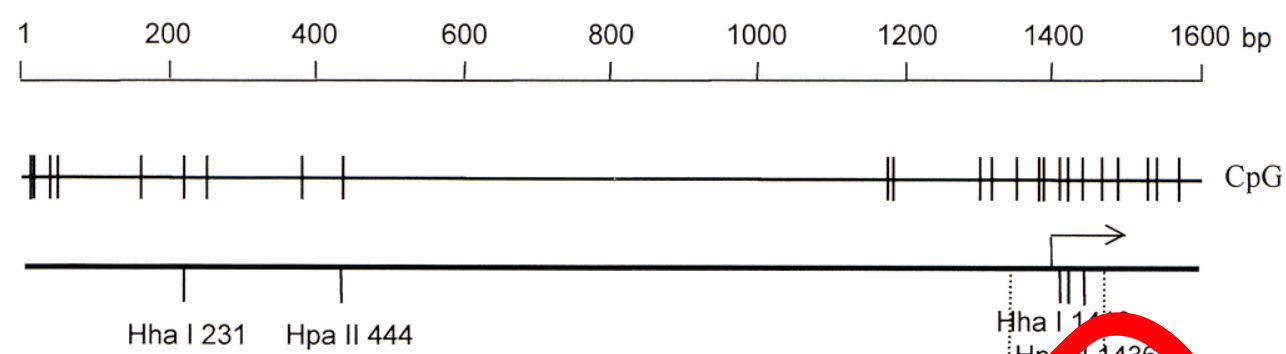

Hha I 231 Hpa II 444

B
D

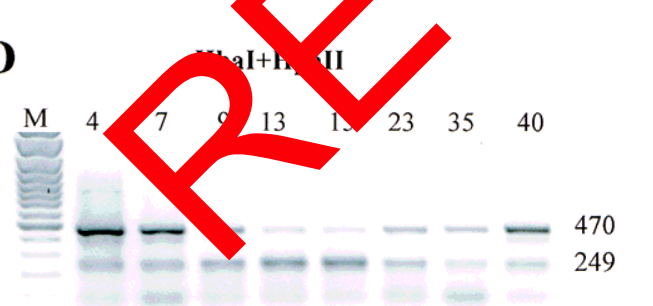

$\mathbf{E}$

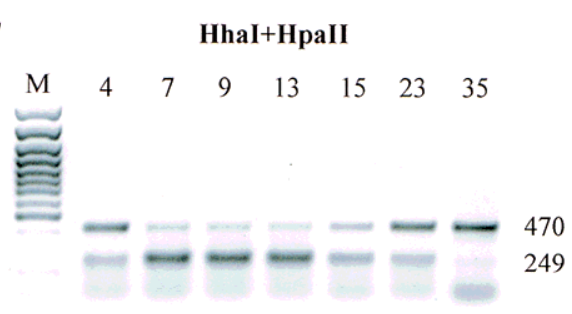

iा 1436

Hha I 145

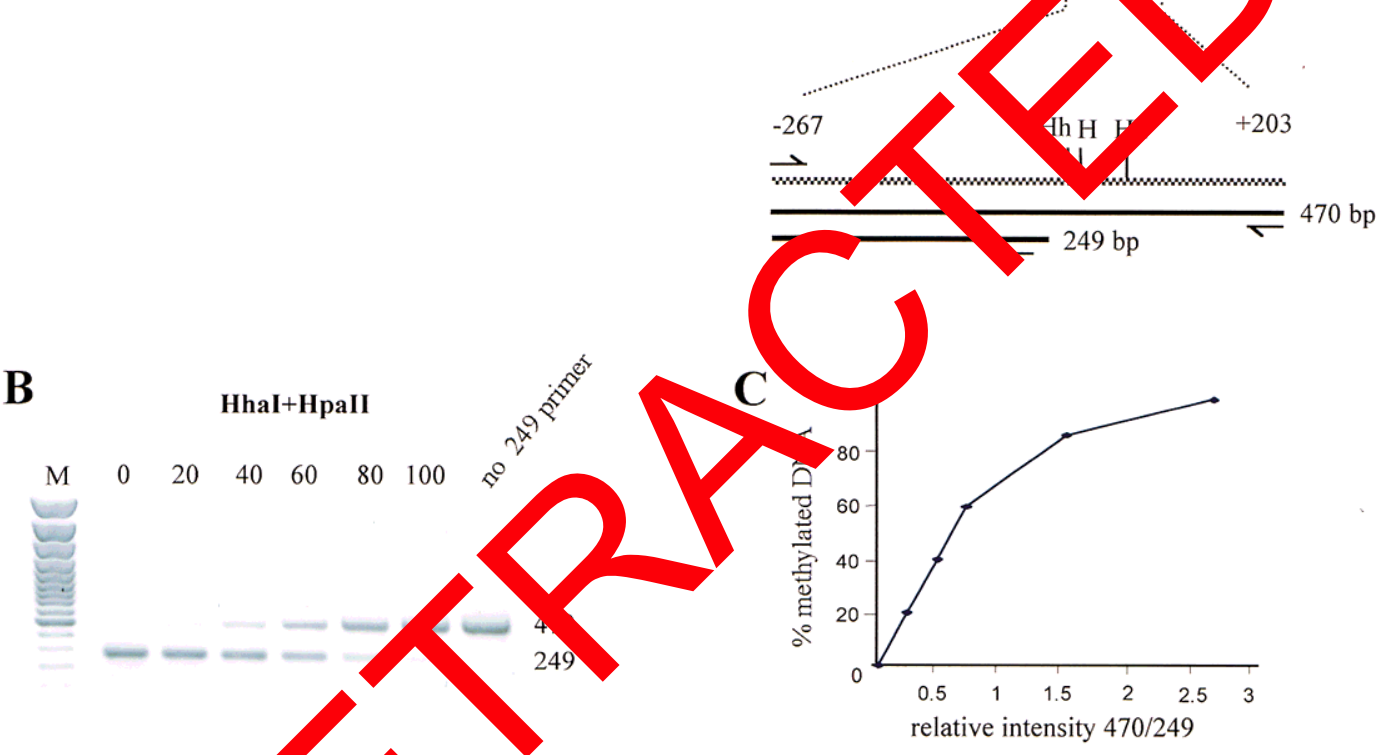

F
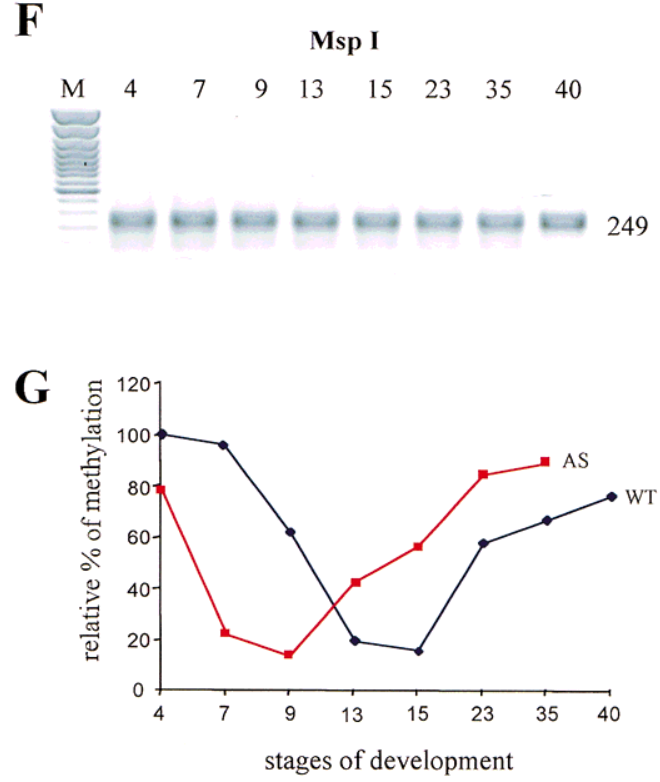

Figure 8. (See facing page for legend.) 
Xbra expression (stage 9-13; Smith et al. 1991) and remain relatively free of methylation until stage 23 (Fig. 8D). In the $x$ Dnmt1-depleted embryos the pattern of methylation is different as the HpaII and HhaI sites are already hypomethylated at stage 4 and at stage 7 , which coincides with the premature activation of Xbra (Fig. $8 \mathrm{E}$ ). These sites also become remethylated earlier (Fig. $8 \mathrm{D}$ and $\mathrm{E}$, cf. Stage 15 and 23 of normal and depleted embryos, respectively). The reduced expression of Xbra in gastrula stage (st. 11) mutant embryos may, in part, be due to de novo methylation of promoter proximal CpGs, but this may also result from the loss of other factors that are necessary for Xbra expression. Although we are looking at whole-embryo DNA, the changes in methylation that we observe in normal embryos are consistent with the idea that these sites are hypomethylated as a consequence of gene activation. More copies of the promoter become hypermethylated after Xbra expression is restricted to a smaller population of cells in the latestage embryo. A graph representing the methylation changes that we observe over the Xbra promoter is shown in Figure 8G. We obtained similar results by Southern blotting (data not shown). In brief the Xbra promoter undergoes developmentally programmed changes in DNA methylation that are disrupted in the $x$ Dnmt1-depleted embryos. The experimentally induced hypomethylation of the Xbra promoter correlates with its premature activation.

\section{Discussion}

xDnmt1 and DNA methylation in Xenopus development

In this paper we attempted to deternine temporal and spatial pattern of $x D n m t 1$ ex ession dun $\mathrm{g}$ Xenopus embryogenesis and found at x nmt1 mKNA is present at all stages of develo me albeit at varying levels. The transcript is ab dant the mature oocyte and persists at $b$ o le els in ave stage embryos but is nonunif mly 1 alized to the animal pole blastomeres. After $\mathrm{Mb}$ ate maternal $\mathrm{xDnmt1}$ is replaced by a zygotic form m considerably lower expression levels. DNA derived frow animal blastomeres is up to three times more methylated than DNA from the vegetal pole cells. The functional relevance of this observation is supported by the fact that vegetal blastomeres are less sensitive to injection of antisense $x D n m t 1$ RNA. Depletion of the maternal $x D n m t 1$ transcript and protein from the animal pole leads to severe developmental defects that can be largely rescued by cross-species (mouse or human) Dnmt1 proteins. Higher levels of Dnmt1 protein cannot be tolerated either by the animal or by the vegetal blastomeres. Transient depletion of maternal $x D n m t 1$ from Xenopus blastulae affects gene activation at MBT and most probably alters the ability of animal blastomeres to undergo neural induction during gastrulation and subsequent differentiation. Unlike the observation in rodents (Monk et al. 1987), but similar to zebrafish (Macleod et al. 1999), we do not detect a dra- matic DNA demethylation step during the early stages of development in whole embryos. Overall $\mathrm{m}^{5} \mathrm{C}$ content decreases toward MBT coinciding with the initiation of zygotic transcription and generally follows the decrease of $x$ Dnmt1 levels. This suggests a passive mechanism of demethylation of Xenopus blastula DNA rather than the involvement of a demethylase activity.

\section{Contribution of methylation to transcriptional silencing before $M B T$}

The MBT is a complex event that occurs at stage 8.5 of Xenopus development and is associated with major changes in the cell cycle, the anpearance of cell cycle checkpoints and initiatio of gotic transcription (Newport and Kirschner 482a; $\mathrm{H}$ we and Newport 1996). A number of dies ave de onstrated that in the early embryo, $c^{\prime}$ omatin a sy efficiently competes with bindi of thscrips on factors to the promoter elemen (1) cau et 1. 1994; Almouzni and Wolffe 1995 This co pet con be experimentally shifted ip avo of transw ption either by prebinding of transcrintion fac 's to microinjected reporter templates (Pri cau et al. 199 Almouzni and Wolffe 1995) or by tre tment of fultured blastomeres with a high concentra on of TC (Kinoshita et al. 1993). Toward MBT the decr in astone concentration and the coupling of heir syntnesis to the cell cycle allows transcription to $b$ rated at a specific nucleus to cytoplasm ratio (Newport and Kirschner 1982b). Somatic linker histones have been shown to play a role in differentiated gene expression (Bouvet et al. 1994; Kandolf 1994) and in the duration of mesodermal competence during gastrulation (Steinbach et al. 1997) whereas the contribution of maternal linker histone, H1M, to overall transcriptional silencing before MBT is unknown.

Recent studies (Jones et al. 1998) and our own observations (R. Meehan and I. Stancheva, unpubl.) have found that Xenopus oocytes and early embryos contain a considerable amount of the methylation specific transcriptional repressor protein MeCP2. This methyl-CpG binding protein acts as a global transcriptional repressor in two ways, either directly inhibiting binding of transcription factors to methylated promoters (Nan et al. 1997) and at the level of chromatin via interaction with Sin3A/histone deacetylase complex (Jones et al. 1998; Nan et al. 1998). Mutation of the MeCP2 gene also causes embryonic lethality in mice but there are no reports that there is a failure of $\mathrm{X}$-inactivation or inappropriate expression of imprinted genes in these mutants (Tate et al. 1996). It is probable that MeCP2 in mice and Xenopus is performing a similar function.

In our experiments transient depletion of maternal $x$ Dnmt1 RNA and protein by antisense RNA injection dramatically decreases the content of $\mathrm{m}^{5} \mathrm{C}$ during the rapid early cleavages. Presumably hypomethylation leads to the exclusion of MeCP2 from chromatin and allows premature gene activation. Interestingly, as suggested by $\left[\alpha-{ }^{35}\right.$ S ] UTP incorporation in the presence of $\alpha$-amanitin, $x$ Dnmt1-depleted blastulae can activate the 
genes transcribed by all three RNA polymerases approximately two cell cycles before MBT (stage 6.5). Our limited RT-PCR analysis allowed us to identify upregulated mRNAs for the mesoderm inducing molecules Cerberus, $X b r a$, and Otx2, however none of these genes can be characterized as being tissue specific in their expression patterns at this stage of development (Smith et al. 1991; Pannese et al. 1995; Bouwmeester et al. 1996). The symmetrical injection of antisense $x D n m t 1$ RNA into both blastomeres at two-cell stage and the ectopic injection into a single animal dorsal blastomere (D1) showed that Cerberus and Xbra transcripts appear in nonoverlapping population of cells and that their patterns of expression greatly resemble that of normal gastrulae (Smith et al. 1991; Bouwmeester et al. 1996). This is consistent with the idea that the Xenopus embryo is prepatterned by maternal gradients of transcription factors and morphogens before MBT (Heasman 1997). Additional experiments are required to identify the full spectrum of genes that are activated in $x D n m t 1$-depleted Xenopus blastulae.

The phenotypes of $x$ Dnmt1-depleted embryos during gastrulation and at the equivalent of stage 35 suggest that loss of methylation during cleavage stages cannot be completely compensated by even higher than normal levels of zygotic methyltransferase. In addition the mesodermal markers Cerberus, Xbra, and Otx2 are downregulated during gastrulation, when normally they are highly expressed (Smith et al, 1991; Pannese et al, 1995; Bouwmeester et al, 1996). One possibility is that loss of methylation and premature expression of genes inappropriate timing of mesoderm induction an eads $p$ negative interference of signalling pathways

other hand, we do not know how essent 1 is loss $x D n m t 1$ and respectively of the initial hylation atterns for the ability of animal pole blartoms s to differentiate since this potential must so be set before MBT (Kinoshita et al. 1993) Disturyed gastrulation movements of antisense-injec en ryos suggests that they face serious signalin robn s. De ste this fact, they seem to divide in a indi ingur re fashion compared with wild-typ siblip chefore gastrulation (R. Meehan and I. Stanchen npub1.).It also cannot be excluded that premature gen ctivation may affect the cell cycle and lead to the appearan.e earlier than usual of cell cycle checkpoints, which results in untimely apoptosis and cell death.

\section{Does DNA methylation have a conserved role in regulation of developmental gene activation?}

At present it has been demonstrated that mice, zebrafish, and frog contain abundant oocyte forms of Dnmt1. Loss or inhibition of the enzyme during early stages is either lethal or leads to abnormal development (Li et al. 1992; Lei et al. 1996; Martin et al. 1999). The maternal forms of Dnmt1 in zebrafish and Xenopus are both present at high levels in the animal pole in oocytes, eggs, and animal blastomeres during early cleavages (Martin et al. 1999; this study). The polarized localization reflects the general uneven distribution of maternal cytoplasm factors that is essential for mesoderm induction both in Xenopus and zebrafish (Wolpert et al. 1998). Oocyte xDnmt1 is almost equally distributed in the nucleus and cytoplasm (Kimura et al. 1999) and RNA transcript levels drop dramatically after the breakdown of germinal vesicle (R. Meehan and I. Stancheva, unpubl.; see also Fig. 1). In mice there is no compartmentalization of the oocyte cytoplasm and the adjustment of nuclear levels of Dnmt1 enzyme is achieved by migration of the protein during oocyte maturation (Carlson et al. 1992; Mertineit et al. 1998). In the course of embryo development in all species Dnmt1 transcripts were found at persistently high levels in the cells of neural origin, an observation that still remains functionally unclear (Goto et al. 1994; Martin et al. 1999). It has be argo that in mice DNA methyltransferase is not sential fo the early embryonic cells. Mouse ES D $\mathrm{gmt}$ cells a viable in culture but die upon differ atiation i al. 1996). Somatic DNA methylatio batte $s$ in mouse embryos are established after a dve senom vide demethylation during preimpl tation (N onl t al. 1987; Razin and Kafri 1994; Po nin and Jarrisch 1996). Such dramatic changes in $\mathrm{m}^{5} \mathrm{C}$. vels were not detected at the onset of gas atation in Xes pus and zebrafish (Macleod et al. 19 9; this st dy). The asymmetric localization of compo nts der ed from the maternal cytoplasm and Dnh itse in these species may allow differential ethylarion patterns to be set up in subsets of cells duri cleavage stages. These patterns will be modified and reinforced by the localized differential expression of the zygotic Dnmt1 during later stages of development. Despite the considerable differences that exist between mammalian development and that of amphibia and fish, it is clear that reduced levels of Dnmt1 and DNA hypomethylation at the onset of embryogenesis result in equally severe phenotypes that bear distinguishable similarities between the different species as indicated by the presence of axial defects, failure to form neural tissue, and improper patterning of the somites (Trasler et al. 1996; Martin et al. 1999|. In Xenopus and zebrafish, mesoderm formation is negatively affected during gastrulation by hypomethylation and some genes such as Cerberus, Otx2, Xbra, and the zebrafish floating head and the brachyury homolog no tail (Martin et al. 1999) are expressed at reduced levels. We show here that maternal $x$ Dnmt1 in Xenopus is essential for maintenance of gene silencing before midblastula transition and that changes in $x D n m t 1$ levels affect differentiation of animal pole blastomeres. Our studies of the Xbra promoter revealed that it undergoes developmentally regulated changes of DNA methylation that coincide with the timing of Xbra expression. Bird (1992) has produced elegant models for transcriptional repression by DNA methylation that depend on a number of parameters: (1) the strength of the promoter; (2) the number and location of methylated CpG pairs; and (3) the presence of methylbinding proteins that can interact with heterochromatin promoting factors. In this dynamic view of methylationmediated gene inactivation there is a shifting balance between activation and repression, which depends on 
the presence of strong transcription factors to activate a methylated gene. Such a scenario may be the normal mode of gene activation during development. Unfortunately this question has not been answered in mice because of the complexity of $D n m t^{-/-}$phenotypes, which is greatly dominated by the negative effect of misexpression of imprinted genes and X-chromosome inactivation (Panning and Jaenisch 1996). We also find that hypomethylation of Xenopus blastulae DNA does not lead to aberrant expression of tissue specific genes, which supports similar observations in mice (Walsh and Bestor 1999). It is possible that many more aspects of the methylation repression machinery are conserved between mammals and amphibia.

\section{Materials and methods}

\section{Cloning of xDnmtl cDNAs}

A stage 20-22 Xenopus $\lambda$ ZapII cDNA library was screened with a pair of $\left[\gamma^{32} \mathrm{P}\right] \mathrm{dATP}$ end-labeled oligonucleotides corresponding to the carboxy-terminal xDnmt sequences: 3811-3831, TTCCAGAGGCAGATTCGTGG and 4271-4291, ACACTCACCACACGATGC. The longest $x D n m t 1$ clone (GenBank accession no.: AF192996) p9/19 containing a 1.4-kb insert in pBluescript SK+ was sequenced and used as a hybridization probe for Northern blot analysis and for synthesis of sense and antisense RNA. A partial 830-bp cDNA xDnmt1 p59/889 corresponding to the oocyte $x D n m t 1$ (Kimura et al. 1996) aminoterminal sequences between base pairs 59 and 889 was obtained by RT-PCR amplification (TrueSprinter RT-PCR ki Ltd.) from Xenopus oocyte RNA using the following

ACTGTGTCCTGTTGATTCGC, (r) TTCTTCCG CCG. The RT-PCR product was cloned into St site $\mathrm{CS} 2+$ plasmid.

\section{Embryos and microinjections}

Xenopus embryos were obtained in ir fitro-fertilized wildtype and albino eggs, grown and mic ,ected cording to the standard procedures. Stagin was con $\mathrm{g}$ Nieuwkoop and Faber (1967). Blastulae (2 4-, 8-, d 16-ce, were injected with $120,400,520$, and $600 \mathrm{pg}$ an per cell or $520 \mathrm{pg}$ of sense capped RNA synthesi. in vitro from xDnmt p9/19 (T3/ T7 Cap-Scribe kit, Boehringer NA was injected into the amimal or vegetal half of the embryos as far as possible from the midline. The ectopic injections of $250 \mathrm{pg}$ of sense or antisense $x D n m t 1$ RNA coinjected with 100 pg of cytoplasmic $\beta$-gal sense RNA were performed into the D1 blastomere of albino eightcell stage embryos $(n=150)$. The hDnmtl and mDnmtl baculovirus-produced proteins (Pradhan et al. 1997) were diluted in sterile water to a final concentration of 1,3 , and $8 \mathrm{ng} / \mu \mathrm{l}$ or in a sterile water containing $130 \mathrm{ng} / \mu \mathrm{l}$ (final concentration) antisense $x$ Dnmt1 RNA prior to microinjection.

\section{Whole-mount in situ hybridization}

The whole-mount in situ hybridizations were performed as described (Harland 1991). Digoxigenin-UTP or fluorescein-labeled probes were prepared using Boehringer reagents. Xbra probe derived from psp73 plasmid (Smith et al. 1991), Cerberus probe was synthesized as described (Bouwmeester et al. 1996), and $x D n m t 13^{\prime}$ and $5^{\prime}$ probes were made from $x D n m t 1 \mathrm{p} 9 / 19$ and
xDnmt1 p59/889, respectively. $\beta$-Gal staining was performed as described previously (Steinbach et al. 1997).

\section{Northern blot analysis}

RNA isolation and Northern blots were carried out according to the standard procedures.

RNA $(15 \mu \mathrm{g})$ from each stage were loaded on the gels. The blots were hybridized with $1.4-\mathrm{kb} x D n m t 1 \mathrm{cDNA}\left[\alpha^{3}{ }^{32} \mathrm{P}\right] \mathrm{dCTP}-$ labeled probe after stripping the filters with Xenopus ODC probe (Isaacs et al. 1992). The signals were detected by conventional autoradiography and by FLA 2000 FluoroImager (FujiFilm) and IP reading, quantified by Aida 2.0 (Advanced Image Digital Analyser) software (FujiFilm, Ltd.), and plotted using Microsoft Excel.

\section{Whole embryo run-on experis nts
Pigmented two-cell-st embryos ere oinjected with $520 \mathrm{pg}$
of antisense or sens $\mathrm{Dnm}+\mathrm{RNA}$ a $50 \mathrm{nCi}\left[\alpha^{35} \mathrm{~S}\right] \mathrm{UTP}(400$ $\mathrm{Ci} / \mathrm{mmole}$, Amema culturs in $4 \%$ Ficoll, $0.2 \times$ Marc's Modified Rino sor in se say buffer containing either 0.2 $\mu \mathrm{g} / \mathrm{ml}$ or $20 \mathrm{co} \mathrm{nl} \alpha$-ama in parallel with the control sib- lings injecued wi $50 \mathrm{nCi}\left[\alpha^{-35} \mathrm{~S}\right] \mathrm{UTP}$ only. Starting from stage 4, sam of 15 injo and control embryos were collected at eac time point and trozen at $-20^{\circ} \mathrm{C}$ prior to being processed. To 1 RNA wa purified by the use of PureScript RNA isolation kit Gentra) at 3 aliquots of $10 \mu \mathrm{l}$ from each sample (final volu of 50 1) were immobilized on glass fiber filters (GF/A) Whatman. The filters were washed subsequently with ice-cold $20 \%$, and $5 \%$ trichloracetic acid. Incorporated label was etected by a Liquid Scintilation Analyzer 1900CA (Packard). \\ RT-PCR analysis}

Total RNA $(1 \mu \mathrm{g})$ from normal and $x D n m t 1$-depleted embryos was treated with RNase free DNase RQ1 (Promega) and reverse transcribed with SuperScript II (BRL Life Technologies). cDNAs were subjected to serial dilutions and with control primers for

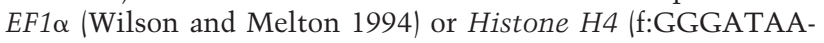
CATTCAGGGTATC, r:CATGGCGGTAACTGTCTTC) to estimate the linear range of PCR amplification. The other pairs of RT-PCR primers were:

xDnmt1 amino-terminal (f: TCTTGTGGATGAATGCGAGG, r:CCACATCATCCTTCCTCT),

$x D n m t 1$ sense/antisense overlap (f:GGCGGTGCAAGGA-

CATTG, r:ACTGGTAGCCCATGCGTAC),

HP1 $\alpha$ (f: CTCAGAGGAGCATAACACTTGG, r:CCTTCTTCATTCAGACACACA),

HP1 $\gamma$ (f:CAAGAAGGTGGAGGAAGC, r:CCAGAGGATGAAGCACAATAAA),

RPD3 (f:ACGGTGATGGTGTTGAGG; r:AGCAACGAGCCACATTCC),

Xbra (f:TGGCTTATTCCTAATGGTGG, r:CTGGCTGTGACTCATTGG),

Cerberus (f:TCATAAGAGCAACTTCCACC, r:TGCTGAT-

TGGTTGTTAGTCC),

Otx2 (f:TACCTGAGTCCAGAGTCC, r:CTGCTGGTAGGTCATAGG),

HoxB9 (f:TACTTACGGGCTTGGCTGGA, r:AGCGTGTAACCAGTTGGCTG),

HoxB3 (f:ATATGATGAGCCACGCAGCAG, r: CAGATGCTGCAGCTCTTTGGC),

Neural $\beta$-tublin (f: ACACGGCATTGATCCTACAG, r: AGCTCCTTCGGTGTAATGAC), 
muscle actin (f: GCTGACAGAATGCAGAAG, r: TTGCTTGGAGGAGTGTGT).

Amplification was performed for Xbra, Otx2, Cerberus, HoxB9, and RPD3 (35 cycles) and for Histone H4, HP1 $\alpha$ and $\gamma$, EF1 $\alpha$ (28 cycles). PCR reactions were analyzed in $1.2 \%$ agarose gels and directly scanned by FLA 2000 FluoroImmager (FujiFilm). All RT-PCRs were repeated at least three times for every set of primers and RNAs and were also peformed in the absence of reverse transcriptase $(-\mathrm{RT})$.

\section{Immunological detection of $m^{5} \mathrm{C}$}

DNA was isolated from 25-50 staged wild-type, antisense $x$ Dnmt1 RNA-injected embryos or from $~ 250$ stage 6 wild-type blastulae that had been separated into animal and vegetal halves. DNA $(5 \mu \mathrm{g})$ from each sample was digested with EcoRI and transferred to Z-probe membrane (BioRad). Dot blots were probed for $\mathrm{m}^{5} \mathrm{C}$ as described (Reynaud et al. 1992; Tweedie et al. 1997) using a monoclonal $\mathrm{m}^{5} \mathrm{C}$ antibody and a secondary antimouse HRP conjugated IgG. Chemiluminiscence signal (ECL reagents, Amersham, Life Technologies) was detected by exposure to Fuji XR films and by scanning with FLA 2000.

\section{Methylation-sensitive PCR analysis}

PCR quantification of methylation at the Xbra promoter was based on a method described by Singer-Sam et al. (1990) and modified for the use of three primers. Total genomic DNA from staged normal and $x$ Dnmt1-depleted embryos was digested to completion with HpaII and HhaI restriction enzymes or with MspI. The complete digestion was monitored by removing a portion of the reaction at time zero and incubating it with a control plasmid (pBluescript SK+). After digestion the were phenol-chloroform, chloroform extracted, ethan tated, and resuspended in distilled water to a final co of $100 \mathrm{ng} / \mu \mathrm{l}$. Undigested DNA samples were amplification range with both pair of prim measure of equal template concentration tion of all three primers that gave line amplifio ion. Competitive PCR reactions $(100 \mu \mathrm{l})$ typice , included $2 \mu \mathrm{s}$, HaII, HhaI, or MspI-digested genomic D A (20 $\$ 1,7$ pmoles of forward primer, 5 pmoles of first revers vri er (249h and 7 pmoles of second reverse primer $(47$ The 1 llowi amplification cycles were used: denaturi at $9 \mathrm{~s}$ for $\mathrm{C}$, annealing for 30 sec at $51^{\circ} \mathrm{C}, 1$-min elong on at of 35 cycles. Xbra promoter primers were as follows. ard CAMCAGCAGTTGCCTCAC; 1 st reverse CTTCGTA SACACAGACTGG; 2nd reverse ACCTTCCATTCTTAGTGAC To create a quantitative standard curve a plasmid containing the Xbra promoter and part of the first Xbra exon (Latinkic et al. 1997) was methylated in vitro by SssI methylase ( $2 \mathrm{hr}$ with addition of SAM after the first hour of incubation). Methylated plasmid (mXbra) was mixed with unmethylated Xbra plasmid in combinations (vol/vol) 10:0, 8:2, $6: 4,4: 6,2: 8$, and 0:10-, all of the mixtures were digested either with HpaII and HhaI or with MspI, and $10 \mathrm{ng}$ of each mixture were used for PCR amplification as described above. All reactions were ethanol precipitated, dissolved in $15 \mu \mathrm{l}$ of $1 \times$ loading buffer, and electrophoresed in $1.2 \%$ agarose gel containing 0.5 $\mu \mathrm{g} / \mathrm{ml}$ ethidium bromide. The gels were scanned by FLA 2000 Fluoroimmager (475 nm excitation index) and the intensity of both 249-bp and 470-bp PCR products was determined by Aida 2.0 software as a peak function in approximate units (AU). The ratio of 470-bp to 249-bp PCR products were plotted versus $\%$ of methylation (\% mXbra in the reaction) for each mixture sample. The standard curve was used to quantify the relative \% of methylation for the endogenous genomic Xbra promoter se- quences by plotting $470 / 249$ values from the agarose gels scans of each reaction for wild type and $x D n m t 1$-depleted embryos against the standard. Each series of PCRs was repeated at least 3 times.

\section{Protein extracts and immunoblots}

Total protein extracts were prepared from staged wild-type eggs, wild-type and antisense $x D n m t 1$-depleted blastulae and gastrulae as described (Evans and Kay 1991) run in 7\% SDS-polyacrylamide gels and electrotransfered to PVDF membrane. xDnm1 was detected by a polyclonal antibody raised against the conserved carboxy-terminal domain of mouse Dnmt1 (Liu et al. 1998), PCNA was detected by a monoclonal PC 10 antibody (Waseem and Lane 1990). Anti-mouse or anti-rabbit HRP-conjugated IgGs were used as secon ribodies. For the immunoprecipitation experiments, rotein o racts were prepared from 200 wild-type 64-cell b. tulae, whi had been dissected to animal and vegetal cres. he imm hoprecipitation was performed according the standa vr edures. Sepharose-protein A beads were w hed ensively with buffer containing 50 $\mathrm{mm}$ Tris, at $\mathrm{pH}$, $\mathrm{MM} \mathrm{Na}, 1 \% \mathrm{NP}-40$, and $0.5 \% \mathrm{Na}$ deoxocholate he boun fract ns were extracted and run in $7 \%$ SDS-p ac lamide ge $\$ D n m t 1$ protein was detected by mouse monoclona ntibody against human Dnmt1.

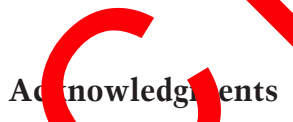

We $\mathrm{nk}$ An Brandli for the Xenopus cDNA libraries, Tewis Rowmeron the Cerberus plasmid, Jim Smith for the Xbra py $\quad$ er clone, Randall Moon for the Xbra and Harry Isaacs for Ie ODC cDNA probes, David Turner for pCS-c $\beta$-gal plasmid, Jean-Paul Jost for the carboxy- and amino-terminal $\mathrm{mDnmt} 1$ ntibodies, Benjamine Li for the monoclonal hDnmtlantibody, Emma Warbrick for the PCNA antibody, and Alain Nevileau for the several shipments of 5-methylcytosine monoclonal antibody and the protocols how to use it. Human and mouse Dnmt1 proteins were kind gift from S. Pradhan. We are grateful to Paul Krieg and to Sally Moody for the extremely well-organized Xenopus course at Cold Spring Harbor Laboratory, (1998) and helpful advice in all that concerned embryology work. We would like to thank Adrian Bird, Jim Allan, Sari Pennings, Colin Davey, and Carmel Reilly for reading and comments on the manuscript. This work was supported by a grant to R.M. from the Wellcome Trust.

The publication costs of this article were defrayed in part by payment of page charges. This article must therefore be hereby marked "advertisement" in accordance with 18 USC section 1734 solely to indicate this fact.

\section{References}

Almouzni, G. and A.P. Wolffe. 1995. Constraints on transcriptional activator function contribute to transcriptional quiescence during early Xenopus embryogenesis. EMBO J. 14: $1752-1765$.

Artinger, M., I. Blitz, K. Inoue, U. Tran, and K.W. Cho. 1997. Interaction of goosecoid and brachyury in Xenopus mesoderm patterning. Mech. Dev. 65: 187-196.

Bestor, T.H. and V.M. Ingram. 1983. Two DNA methyltransferases from murine erythroleukemia cells: purification, sequence specificity, and mode of interaction with DNA. Proc. Natl. Acad. Sci. 80: 5559-5563.

Bird, A. 1992. The essentials of DNA methylation. Cell 70: 5-8. Bouvet, P., S. Dimitrov, and A.P. Wolffe. 1994. Specific regula- 
tion of Xenopus chromosomal 5S rRNA gene transcription in vivo by histone H1. Genes \& Dev. 8: 1147-1159.

Bouwmeester, T., S. Kim, Y. Sasai, B. Lu, and E.M. De Robertis. 1996. Cerberus is a head-inducing secreted factor expressed in the anterior endoderm of Spemann's organizer. Nature 382: 595-601.

Carlson, L.L., A.W. Page, and T.H. Bestor. 1992. Properties and localization of DNA methyltransferase in preimplantation mouse embryos: Implications for genomic imprinting. Genes \& Dev. 6: 2536-2541.

Colot, V. and J.-L. Rossignol. 1999. Eukaryotic DNA methylation as a evolutionary device. BioEssays 21: 402-411.

Evans, J.P. and B.K. Kay. 1991. Biochemical fractionation of oocytes. Methods Cell Biol. 36: 133-148.

Goto, K., M. Numata, J.I. Komura, T. Ono, T.H. Bestor, and H. Kondo. 1994. Expression of DNA methyltransferase gene in mature and immature neurons as well as proliferating cells in mice. Differentiation 56: 39-44.

Gurdon, J.B., R.A. Laskey, and O.R. Reeves. 1975. The developmental capacity of nuclei transplanted from keratinized skin cells of adult frogs. J. Embryol. Exp. Morphol. 34: 93-112.

Harland, R.M. 1991. In situ hybridization: An improved wholemount method for Xenopus embryos. Methods Cell Biol. 36: 685-695.

Harland, R. and J. Gerhart. 1997. Formation and function of Spemann's organizer. Annu. Rev. Cell. Dev. Biol. 13: 611667.

Heasman, J. 1997. Patterning the Xenopus blastula. Development 124: 4179-4191.

Howe, J.A. and J.W. Newport. 1996. A developmental timer regulates degradation of cyclin E1 at the midblastula transition during Xenopus embryogenesis. Proc. Natl. Acad. Sci. 93: 2060-2064.

Issacs, H.V., D. Tannahill, and J.M.W. Slack. 1992. Ex a novel FGF in the Xenopus embryo. A new ducing factor for mesoderm formation and tero erior specification. Development 114: 711-720

Jones, P.L., G.J. Veenstra, P.A. Wade, D. Ve Maà S.U. Kass, J. Landsberger, J. Strouboulis, and A.PWolffe. 1) Methylated DNA and MeCP2 recruit his ne deacetylase repress transcription. Nat. Genet. 19:

Kandolf, H. 1994. The H1A histone ri tis an vivo repressor of oocyte-type $5 S$ gen nsch ion ir Aenopus laevis embryos. Proc. Natl. A d. So 91: 7. 7261.

Kass, S.U., N. Landsber and abolffe. 1997a. DNA methylation directs a time-c aent repression of transcription initiation. Curr. Biol. 7: \-165.

Kass, S.U., D. Pruss, and A.P. llffe. 1997b. How does DNA methylation repress transcription? Trends Genet. 13: 444449.

Kimura, H., G. Ishihara, and S. Tajima. 1996. Isolation and expression of a Xenopus laevis DNA methyltransferase cDNA. J. Biochem. (Tokyo) 120: 1182-1189.

Kimura, H., I. Suetake, and S. Tajima. 1999. Xenopus maintenance-type DNA methyltransferase is accumulated and translocated into germinal vesicles of oocytes. J. Biochem. (Tokyo) 125: 1175-1182.

Kinoshita, K., T. Bessho, and M. Asashima. 1993. Competence prepattern in the animal hemisphere of the 8-cell-stage Xenopus embryo. Dev. Biol. 160: 276-284.

Latinkic, B.V., M. Umbhauer, K.A. Neal, W. Lerchner, J.C. Smith, and V. Cunliffe. 1997. The Xenopus Brachyury promoter is activated by FGF and low concentrations of activin and suppressed by high concentrations of activin and by paired-type homeodomain proteins. Genes \& Dev. 11: 32653276.
Lei, H., S.P. Oh, M. Okano, R. Juttermann, K.A. Goss, R. Jaenisch, and E. Li. 1996. De novo DNA cytosine methyltransferase activities in mouse embryonic stem cells. Development 122: 3195-3205.

Li, E., T.H. Bestor, and R. Jaenisch. 1992. Targeted mutation of the DNA methyltransferase gene results in embryonic lethality. Cell 69: 915-926.

Li, E., C. Beard, and R. Jaenisch. 1993. Role for DNA methylation in genomic imprinting. Nature 366: 362-365.

Liu, Y., E.J. Oakeley, L. Sun, and J.P. Jost. 1998. Multiple domains are involved in the targeting of the mouse DNA methyltransferase to the DNA replication foci. Nucleic Acids Res. 26: 1038-1045.

Lombardo, A. and J.M. Slack. 1997. Inhibition of eFGF expression in Xenopus embryos by antisense mRNA. Dev. Dyn. 208: 162-169.

Macleod, D., V. Clark, and A Bird. 19 Absence of genomewide changes in DNA ma vlation do ing development of the zebrafish (Danio rio). $>$ Gene 23: 139-140.

Martin, C.C., L. Lafor ct, M.A Ak_ o, and M. Ekker. 1999. A role for DNA thyl on in gavrulation and somite patterning. Dey siol. 189-2

Mertineit, C A. Yode, T. T eto, D.W. Laird, J.M. Trasler, and $\mathrm{T}, \mathrm{B}$ ror. 1998. ex-specific exons control DNA methyltransfer. in mammalian germ cells. Development 12 - 897.

Mc k, M., M. Boubelik, and S. Lehnert. 1987. Temporal and egional ch. ges in DNA methylation in the embryonic, exembryon and germ cell lineages during mouse embryo de 1 nit. Development 99: 371-382.

X., F.J. Campoy, and A. Bird. 1997. MeCP2 is a transcription repressor with abundant binding sites in genomic chromatin. Cell 88: 471-481.

Nan, X., H.H. Ng, C.A. Johnson, C.D. Laherty, B.M. Turner, R.N. Eisenman, and A. Bird. 1998. Transcriptional repression by the methyl-CpG-binding protein MeCP2 involves a histone deacetylase complex. Nature 393: 386-389.

Newport, J. and M. Kirschner. 1982a. A major developmental transition in early Xenopus embryos: I. Characterization and timing of cellular changes at the midblastula stage. Cell 30: 675-686.

- 1982b. A major developmental transition in early Xenopus embryos: II. Control of the onset of transcription. Cell 30: 687-696.

Nieuwkoop, P.D. and J. Faber. 1967. Normal table of Xenopus (Daudin). Elsevier North Holland, Amsterdam, The Netherlands.

Okano, M., S. Xie, and E. Li. 1998. Cloning and characterization of a family of novel mammalian DNA (cytosine-5) methyltransferases. Nat. Genet. 19: 219-220

Pannese, M., C. Polo, M. Andreazzoli, R. Vignali, B. Kablar, G. Barsacchi, and E. Boncinelli. 1995. The Xenopus homologue of Otx2 is a maternal homeobox gene that demarcates and specifies anterior body regions. Development 121: 707-720.

Panning, B. and R. Jaenisch. 1996. DNA hypomethylation can activate Xist expression and silence X-linked genes. Genes \& Dev. 10: 1991-2002.

Pradhan, S., D. Talbot, M. Sha, J. Benner, L. Hornstra, E. Li, R. Jaenisch, and R.J. Roberts. 1997. Baculovirus-mediated expression and characterization of the full-length murine DNA methyltransferase. Nucleic Acids Res. 25: 4666-4673.

Prioleau, M.N., J. Huet, A. Sentenac, and M. Mechali. 1994. Competition between chromatin and transcription complex assembly regulates gene expression during early development. Cell 77: 439-449.

Razin, A. and T. Kafri. 1994. DNA methylation from embryo to 
adult. Prog. Nucleic Acid Res. Mol. Biol. 48: 53-81.

Reynaud, C., C. Bruno, P. Boullanger, J. Grange, S. Barbesti, and A. Niveleau. 1992. Monitoring of urinary excretion of modified nucleosides in cancer patients using a set of six monoclonal antibodies. Cancer Lett. 61: 255-262.

Singer-Sam, J., M. Grant, J.M. LeBon, K. Okuyama, V. Chapman, M. Monk, and A.D. Riggs. 1990. Use of a HpaII-polymerase chain reaction assay to study DNA methylation in the Pgk-1 CpG island of mouse embryos at the time of Xchromosome inactivation. Mol. Cell. Biol. 10: 4987-4989.

Smith, J.C. B.M. Price, J.B. Green, D. Weigel, and B.G. Herrmann. 1991. Expression of a Xenopus homolog of Brachyury $(\mathrm{T})$ is an immediate-early response to mesoderm induction. Cell 67: 79-87.

Steinbach, O.C., A.P. Wolffe, and R.A. Rupp. 1997. Somatic linker histones cause loss of mesodermal competence in Xenopus. Nature 389: 395-399.

Steinbeisser, H., A. Fainsod, C. Niehrs, Y. Sasai, and E.M. De Robertis. 1995. The role of gsc and BMP-4 in dorsal-ventral patterning of the marginal zone in Xenopus: A loss-of-function study using antisense RNA. EMBO J. 14: 5230-5243.

Tate, P., W. Skarnes, and A. Bird. 1996. The methyl-CpG binding protein MeCP2 is essential for embryonic development in the mouse. Nat. Genet. 12: 205-208.

Thiebaud, C.H., B. Colombelli, and W.P. Muller. 1984. Diploid gynogenesis in Xenopus laevis and the localization with respect to the centromere of the gene for periodic albinism ap. J. Embryol. Exp. Morphol. 83: 33-42.

Trasler, J.M., D.G. Trasler, T.H. Bestor, E. Li, and F. Ghibu. 1996. DNA methyltransferase in normal and Dnmtn/ Dnmtn mouse embryos. Dev. Dyn. 206: 239-247.

Tweedie, S., J. Charlton, V. Clark, and A. Bird. 1997. Methylation of genomes and genes at the invertebrate-ver boundary. Mol. Cell. Biol. 17: 1469-1475.

Tymowska, J. 1991. Polyploidy and cytogenetic frogs of the genus Xenopus. In Amphibian cy gen and evolution (ed. D.M. Green and S.K. Sessi \$), pp. 25, 297. Academic Press, San Diego, CA.

Walsh, C.P. and T.H. Bestor. 1999. Cy sine met lation and mammalian development. Genes Dev. 13: 26-0

Waseem, N.H. and D.P. Lane. 90. N Moclonal antibody analysis of the proliferating ce ny cear antigen (PCNA). Structural conservation he a ection $A$ the nucleoar form. J. Cell Sci. 96: 12 129 .

Wilson, P.A. and D.A. $N$ ton. 1 M Mesodermal patterning by an inducer gradient dep on secondary cell- cell communication. Curr. Biol. 4: 6> 686.

Wolpert, L., R. Beddington, J. D ckes, T. Jessel, P. Lawrence, and E. Meyerowitz 1998. Principles of development, 1st ed. Oxford University Press, Oxford, UK.

Yamada, Y., Y. Hagiwara, K. Shiokawa, Y. Sakaki, and T. Ito. 1999. Spatiotemporal, allelic, and enforced expression of Ximpact, the Xenopus homolog of mouse imprinted gene impact. Biochem. Biophys. Res. Commun. 256: 162-169. 


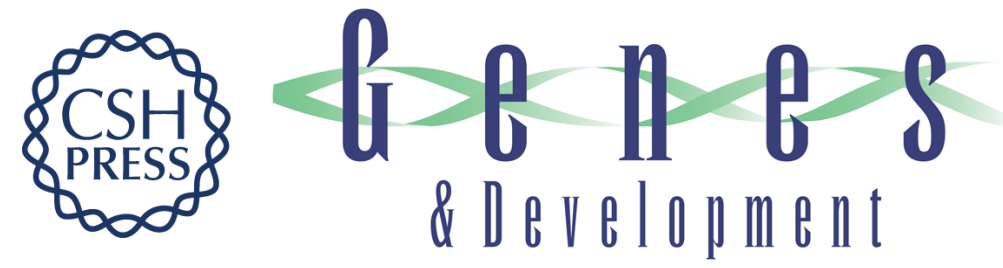

\section{Transient depletion of xDnmt1 leads to premature gene activation in Xenopus embryos}

Irina Stancheva and Richard R. Meehan

Genes Dev. 2000, 14:

Access the most recent version at doi:10.1101/gad.14.3.313

References

This article cites 56 articles, 17 of which can be accessed frer http://genesdev.cshlp.org/content/14/3/313.full.html\#re' /st-1

License

Email Alerting

Receive free email alerts when new articles cite th arti - sign up in the box at the top Service right corner of the article or click here.

\section{Custom LNA Oligos $30 \%$ off offered}




\section{RETRACTION}

Genes \& Development 14: 313-327 (2000)

\section{Retraction: Transient depletion of xDnmt1 leads to premature gene activation in Xenopus embryos}

Irina Stancheva and Richard R. Meehan

Genes \& Development is retracting this article after an investigation led by the University of Edinburgh found that Dr. Irina Stancheva inappropriately manipulated data presented in Figures $6 \mathrm{~F}, 8 \mathrm{~B}, 8 \mathrm{D}$, and $8 \mathrm{~F}$ and likely in Figure $3 \mathrm{~A}$. Based on the University of Edinburgh's investigation panel findings, the editors have decided the best course of action is to retract the paper. Dr. Stancheva and Dr. Meehan could not be reached and therefore have not agreed to the text of this Retraction.

doi: $10.1101 / \operatorname{gad} .327486 .119$ 


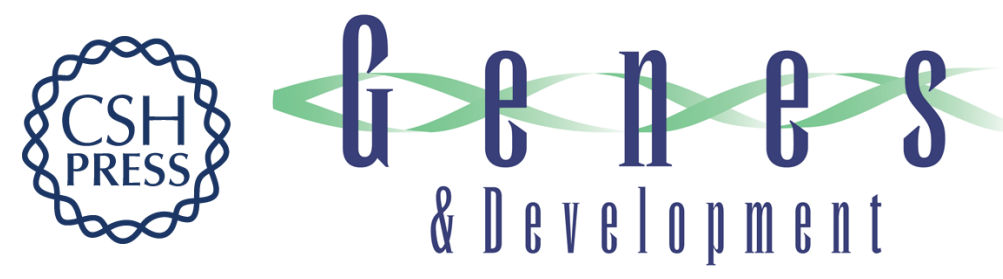

\section{Transient depletion of xDnmt1 leads to premature gene activation in Xenopus embryos}

Irina Stancheva and Richard R. Meehan

Genes Dev. 2000, 14:

Access the most recent version at doi:10.1101/gad.14.3.313
Related Content Retraction: Transient depletion of xDnmt1 leads to premature gene activation in Xenopus embryos
Irina Stancheva and Richard R. Meehan
Genes Dev. June, 2019 33: 737
References This article cites 56 articles, 17 of which can be accessed free at:
http://genesdev.cshlp.org/content/14/3/313.full.html\#ref-list-1
Articles cited in:
http://genesdev.cshlp.org/content/14/3/313.full.html\#related-urls

\section{License}
Email Alerting
Service
Receive free email alerts when new articles cite this article - sign up in the box at the top right corner of the article or click here.

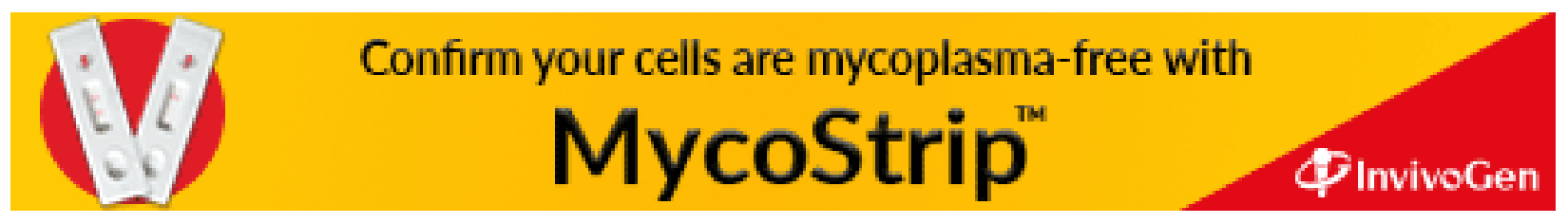

